\title{
Desenhos de figurinos de Alexandra Exter para Aelita, rainha de Marte
}

Costume designs of Alexandra Exter to Aelita, queen of Mars

DOI: 10.20396/rhac.vil.13681

PRISCYLA KELLY VIEIRA ABREU

Mestra em Artes pela Universidade Federal de Uberlândia (UFU)

(D) 0000-0002-4229-4823

\section{Resumo}

Este artigo abarca os figurinos elaborados pela artista russa Alexandra Exter (1882-1949) para o filme de ficção científica Aelita, Rainha de Marte e busca compreender as soluções visuais elaboradas por ela para os personagens extraterrestres, sobretudo a figura feminina que protagoniza o filme. Por meio da análise comparativa de imagens, observamos que os trajes elaborados para Aelita apresentam tanto características inovadoras e preceitos vanguardistas quanto fórmulas visuais convencionais e orientalistas. Nossa postura metodológica se pauta nas práticas de Aby Warburg.

Palavras-chave: Ficção científica. Figurinos. Vanguarda.

\begin{abstract}
This paper covers the costumes made by Russian artist Alexandra Exter (1882-1949) for the science fiction Aelita, Queen of Mars and seeks to understand the visual solutions elaborated by Exter for the extraterrestrial characters, especially the central female figure who stars in the movie. Through the comparative analysis of images, we observe that the costumes elaborated for the film present both innovative features and avant-garde precepts as well as conventional visual formulas. The methodological posture is based on the practices of Aby Warburg.
\end{abstract}

Keywords: Science fiction. Costume design. Avant-garde. 


\section{Desenhos de figurinos de Alexandra Exter para Aelita, rainha de Marte}

Aelita, Rainha de Marte (1924) foi baseado no romance homônimo de Alexei Tolstoi, e dirigido por Yakov Protazanov. O filme abarca o período pós-revolucionário e se passa em Moscou, no início do novo regime político. Sua narrativa perpassa questões econômicas e as mudanças sociais resultantes da revolução, bem como a fantasia do que seria a vida no planeta vermelho. Em Aelita, o engenheiro Los planeja uma viagem a Marte após receber mensagens misteriosas pelo rádio. Após chegar ao planeta, Los conhece a personagem Aelita e participa de um levante da população local contra o poder autoritário que acabara de se instaurar. Apontado como o primeiro filme soviético de ficção científica, além de intentar expressar as questões políticas do país daquele período, também apresenta soluções e inovações visuais vanguardistas:

Na nova Rússia da União Soviética que está sendo, nos anos de 1920, um laboratório de biopolítica para o mundo, não se pode falar, por exemplo, de tortura, de multidões esfomeadas, de trabalhos alienados, de profusão de camponeses chegando nos trens sem saber onde nem por que. Pode-se, sim, projetar tudo para Marte. Em Marte existe a escravidão mais infame, a falta de liberdade de expressão, a coerção do amor, as mulheres liberadas das agruras domésticas, o visual expressionista, a beleza plástica, o estranho como cotidiano. Não se trata só de driblar um problema de censura estúpida, nem de simples autocensura ou policiamento burocrático. É também um problema artístico e de representação: como fazer arte com esses elementos, como estetizar esses novos paradigmas do cotidiano, como fazê-los entrar na trajetória da arte. ${ }^{1}$

Protazanov permaneceu em exílio voluntário após a Revolução de 1917, e retornou a Moscou em 1923, ano em que iniciou a direção de Aelita. Ao retornar, deparou-se com o novo ambiente político instaurado após a revolução, o qual intervinha diretamente no âmbito das artes. O diretor cresceu em Moscou, onde frequentava o teatro assiduamente, o que despertou seu interesse pela indústria cinematográfica. De acordo com Hunt, Protazanov tornou-se um dos diretores mais prolíficos na Rússia e sempre preferiu trabalhar com atores teatrais. Talvez esta aproximação também tenha motivado sua escolha por Alexandra Exter para a elaboração dos figurinos de Aelita². Sobre essa relação, Ripellino aponta que, no teatro de Tairov, o volume das vestes e os planos angulares a cobrir o corpo dos atores

\footnotetext{
${ }^{1}$ RAVETTI apud LEZO, Denise. Arquitetura, Cidade e Cinema: vanguardas do imaginário. Dissertação (Mestrado em Arquitetura e Urbanismo) - Escola de Engenharia de São Carlos, USP, 2010, p. 78. Disponível em http://www.teses.usp.br/teses/disponiveis/18/18142/tde-14092010-101531/pt-br.php. Acesso em: 18 mar. 2017.

${ }^{2}$ Ver HUNT, Laura A. From Performer to Petrushka: A Decade of Alexandra Exter's Work in Theater and Film. Dissertação (Mestrado em Artes) - Arts and Design Department, Georgia State University, Atlanta, 2011. p. 64. Disponível em: http://scholarworks.gsu.edu/art_design_theses/70. Acesso em: 20 mar. 2017.
} 
eram tão marcantes que os personagens ficavam semelhantes aos da ficção científica; por isso adaptaram-se tão bem aos marcianos de Aelita ${ }^{3}$.

Segundo Denise ]. Youngblood, "nenhum outro filme do cinema soviético antigo foi atacado de forma tão consistente ou durante um período tão longo quanto Aelita" ${ }^{4}$. O filme baseado no romance carregado de mensagem pró-comunista e a construção cenográfica futurista pareciam compor a narrativa ideal para a audiência daquele momento. Porém, Protazanov alterou o final da história, colocando toda a passagem por Marte como apenas um sonho, desvinculando-o, segundo Hunt ${ }^{5}$, da narrativa ideológica e posicionando-o como puro entretenimento, a sugerir que a Rússia não era um ambiente satisfatório, levando o homem a buscar descanso em um mundo imaginário. Ainda segundo a autora, a obra foi acusada de formalismo e percebida como antissoviética, sendo mal recebida pelos críticos e banida do país em que foi produzida. Contudo, o filme estreou com grande aparato publicitário e obteve sucesso de bilheteria, além de conquistar o reconhecimento internacional. Talvez, devido ao ambiente político no qual foi produzido, a crítica russa tenha se voltado para o conteúdo ideológico e político. Com isso, segundo Hunt, durante décadas pouca ou nenhuma menção foi feita sobre a cinematografia, a cenografia e o desempenho dramático de Aelita. ${ }^{6}$

O orçamento disponibilizado para o filme, em comparação ao das produções teatrais, parece ter contribuído na criação de Exter para o ambiente marciano. A artista utilizou os mais recentes materiais industriais para a composição cenográfica da mais moderna mídia artística daquele período - o cinema. Como aponta Hunt, o uso de tais materiais

deve ser interpretado como uma declaração ousada que anuncia o triunfo da nova

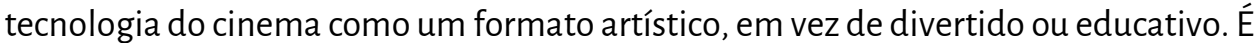
assim possível ler o seu trabalho como formalista, reconhecendo, ao mesmo tempo, a sua tácita reflexão dos ideais soviéticos. ${ }^{7}$

Isaac Rabinovich, aluno de Alexandra Exter, contribuiu no projeto cenográfico que representou o planeta Marte [Figuras 1 - 3]. A abstração do ambiente criado por Rabinovich segue as características da vanguarda russa e, como é possível observar no filme, as formas e mecanismos do cenário não atuam isoladamente, estabelecem um diálogo com outros elementos que compõem a cena, como os figurinos (por exemplo, o traje do personagem Gor, guardião da energia, construído com materiais translúcidos,

\footnotetext{
${ }^{3}$ Ver RIPELLINO, Angelo Maria. O truque e a alma. São Paulo: Perspectiva, 1996, p. 360.

${ }^{4}$ YOUNGBLOOD apud HUNT, op. cit., p. 65. Tradução nossa.

${ }^{5}$ Ver HUNT, op. cit., p. 66.

${ }^{6}$ Ibidem.

${ }^{7}$ Ibid, p. 67. Tradução nossa.
} 
condiz com o mobiliário do ambiente no qual está inserido - figura 1). Entre os desenhos de trajes de Alexandra Exter para Aelita, muitos parecem incorporar construções mecânicas à figura humana, a acentuar o diálogo entre a imagem criada para os habitantes de Marte e o ambiente em que vivem.

Em conformidade às características futuristas e ao culto à cidade moderna [Figura 3], os fios que atravessam as torres sobre as construções de Marte certamente fazem alusão à energia elétrica, algo novo naquele período. Nesse aspecto, podemos citar a obra de Albert Robida intitulada Le Vingtième Siècle, La Vie Électrique, a ilustrar a importância atribuída à energia elétrica e às inovações tecnológicas naquele contexto. Publicado em 1892, o livro ilustrado é o último da trilogia que inclui Le Vingtième Siècle (1882) e La Guerre au Vingtième Siècle (1887), a sintetizar as ideias que o autor havia acumulado durante onze anos sobre o futuro ${ }^{8}$. Uma das ilustrações de Robida [Figura 4] mescla a atmosfera das cidades do início do século XX e as máquinas voadoras futuristas, com inúmeros fios elétricos passando por postes sobre as ruas.

A alusão à energia elétrica também foi representada através de figuras femininas. Como aponta Julie Wosk ${ }^{9}$, em muitas imagens do século XIX as mulheres aparecem como deusas a celebrar a luz, cujos corpos foram "maravilhosamente - algumas vezes assustadoramente - transformados através da eletricidade" ${ }^{10}$. Ainda segundo a autora, muitos artistas representaram mulheres nuas como a encarnação da verdade, com as mãos estendidas a produzir a luz ${ }^{11}$, como na obra La Vérité, de Lefebvre [Figura 5]. O gesto se repete na Sra. Vanderbilt trajando o Electric Light Dress, de Charles Frederich Worth [Figura 6], e na ilustração Dawn of the Century [Figura 7], com a figura feminina no centro das principais inovações do período. Nesta última, a luz não está na mão da personagem, mas em sua tiara, com o pingente da lâmpada contornado por raios.

Estas mulheres tornaram-se símbolo da era elétrica moderna ${ }^{12}$, vindo a ecoar na obra de Robida, em L'életricité [Figura 8], com la glande esclave irradiando luz dos cabelos em linhas retas brilhantes, muito semelhantes às pontas do capacete de Aelita. Nessa ilustração, a menção à energia elétrica é intensificada pelos relâmpagos e pela lâmpada acesa acima da figura feminina. A crista de raios pontudos em torno da lâmpada estabelece relação com os cabelos da personagem (e com Aelita), além disso está sustentada por um longo braço ereto, a ecoar o gesto de La Vérité [Figura 5].

\footnotetext{
${ }^{8}$ Ver EVANS, Arthur; WILLENS, Phillip; ROBIDA, Albert. The Twentieth Century. Wesleyan University Press, 2004.

${ }^{9}$ Ver WOSK, Julie. Women and the machine: Representations from the spinning wheel to the electronic age. JHU Press, 2003.

${ }^{10}$ Ibid., p. 69. Tradução nossa.

${ }^{11}$ Ibid.

${ }^{12}$ Ibid.
} 
A obra de Robida relata a vida que se passa na França no futuro, com inovações tecnológicas, transportes aéreos, telefonoscópios ${ }^{13}$, bem como questões sociais, como a emancipação das mulheres. Contudo, a figura central da ilustração L'electricité diverge das representações de mulheres que conduzem a luz com postura ereta e aspecto confiante. No desenho de Robida, a mulher não é portadora da luz, mas parece trabalhar incansavelmente para gerar energia e mantê-la acesa. A máquina manuseada pela grande escrava também contrapõe às inovações tecnológicas do cartaz Dawn of the Century, pois se de um lado foram representadas de maneira positiva, como conquistas do alvorecer do novo século, por outro parecem instrumentos dos quais a humanidade tornaria escrava.

Aelita compartilha semelhanças visuais com a grande escrava de Robida. No desenho de Exter [Figura 13], as linhas retas em torno da cabeça são semelhantes aos fios de cabelo eletrificados de L'electricité e certamente também fazem menção à energia. Mas em comparação às representações de mulheres condutoras da luz, a Aelita de Exter tem a pose confiante. Embora com resultados visuais diferentes, as vestes da figura feminina de Dawn of the Century e de Aelita são compostas por linhas curvas diagonais, sobretudo na saia. A posição do rosto com o olhar direcionado para a direita do observador também é comum às duas personagens, bem como um dos braços estendido para baixo com a mão arqueada. Os trajes são distintos, de um lado o clássico e de outro o vanguardista, contudo a aproximação de detalhes formais posiciona as duas representações em uma mesma atmosfera de exaltação à tecnologia. No filme Aelita, a montagem de Marte evoca claramente os avanços tecnológicos, não somente nas máquinas e instrumentos que compõem o cenário como também nos figurinos construídos com materiais industriais. Todas essas imagens contrastantes apontam que a energia elétrica e as máquinas nem sempre foram representadas de maneira positiva e deram forma às esperanças e medos ${ }^{14}$ em torno das novidades daquele período.

A transição para a sociedade mais modernizada possibilitou transformações nas estruturas econômicas e sociais, bem como o uso de novas tecnologias. Nesse momento, o teatro de vanguarda e o ateliê de muitos artistas funcionaram como laboratórios de pesquisas científicas, sendo que os novos modos de produção resultaram no deslocamento do suporte artístico para meios mais experimentais ${ }^{15}$, dentre os quais podemos destacar os figurinos. Aelita apresenta as questões ideológicas sobre os usos da ciência e da arte, a combinar, segundo Sue-Ellen Case, o espetáculo construtivista de Marte e a narrativa realista da Moscou contemporânea. Ainda segundo a autora, grande parte do reconhecimento que Aelita

\footnotetext{
${ }^{13}$ Dispositivo de comunicação capaz de transmitir imagens.

${ }^{14}$ WOSK, op. cit., p. 69

${ }^{15}$ Ver CASE, Sue-Ellen. Performing Science and the Ritual. Routledge, 2007, p. 109.
} 
recebeu se deve aos figurinos e projeto cenográfico. Os desenhos de Exter para esta produção tornaramse importantes exemplos da cenografia cubo-futurista ${ }^{16}$.

Inspirando-se no imaginário espacial e nos preceitos vanguardistas, Alexandra Exter desenhou os figurinos dos habitantes de Marte. Dentre as produções teatrais realizadas pela artista nos anos anteriores, com temas mais tradicionais, talvez Aelita tenha sido a mais desafiadora. Além das formas geométricas sempre presentes em seus trabalhos, Exter elaborou engenhosidades mecânicas para o vestuário [Figura 11] e explorou a gestualidade como elemento constitutivo da composição do traje. Como aponta Lezo, Aelita foi um dos primeiros filmes a abordar o cenário e os figurinos como extensões aos movimentos corporais dos personagens, atuando de maneira ativa e dinâmica na execução da cena ${ }^{17}$. Sue-Ellen Case também comenta sobre a relação do figurino com o movimento corporal:

Os figurinos de Exter eram considerados por seus elementos geométricos, que abstraem o movimento do corpo do ator. [...] os cetins usados por baixo das formas geométricas criaram uma tensão estética com abstrações, revelando o corpo do ator e seu movimento em linhas fluidas em contraste ao movimento mecânico do exoesqueleto. [...] tecidos e materiais sintéticos interagiam de maneira dinâmica com a geometria das formas. ${ }^{18}$

Além disso, Exter mesclou diversas texturas de materiais industriais - plástico, alumínio, vidro e metal - de maneira a criar contrastes na imagem projetada no filme em preto e branco. Como aponta Bowlt, os materiais aplicados na construção do cenário e figurinos "definiram a forma em um espaço ausente de cor; em sua transparência ou refletividade eles ingressaram no espaço e criaram uma excêntrica montagem de formas" ${ }^{19}$. A ausência de cor nas produções cinematográficas certamente foi uma característica desafiadora para os artistas da vanguarda russa e incitou a criação de artifícios visuais, como objetos brilhantes, translúcidos, com refletividade.

O uso de materiais metálicos e transparentes como artifício para causar efeitos visuais nos filmes em preto e branco também pode ser observado em produções posteriores, por exemplo o musical Just Imagine, dirigido por David Butler, em 1930. O filme também segue a linha de ficção científica e, semelhante a Aelita, apresenta como uma das personagens principais Loo Loo [Figura 12], a rainha que recebe os cientistas em Marte. Elaborado por Sophia Wachner, o figurino de Loo Loo foi confeccionado em material com aspecto metálico e pequenas placas geométricas sobrepostas a formar o efeito de

\footnotetext{
${ }^{16}$ Ibid., p. 109.

${ }^{17}$ LEZO, op. cit., p. 108

${ }^{18}$ CASE, op. cit., p. 110. Tradução nossa.

${ }^{19}$ BOWLT apud CHRISTIE, Ian; TAYLOR, Richard. Inside the Film Factory: New Approaches to Russian and Soviet Cinema. Routledge, 2005
} 
escamas. O traje também apresenta características futuristas, bem como um exótico acessório de cabeça. As vestes de Loo Loo, como as de Aelita, exibem desnudamento de partes do corpo e evidenciam os contornos femininos, porém, não enfatizando tanto as linhas curvas quanto as retas e oblíquas. Nesse sentido, o figurino de Loo Loo se aproxima mais ao da Salomé de Exter; ambos, por sua vez, contrastam com o de Aelita em sua aparente busca por um equilíbrio entre retilíneo e curvilíneo.

Para o figurino de Aelita, Exter aplicou uma modelagem complexa. As vestes da personagem têm aspecto brilhante, metálico e formas circulares dispostas em movimento helicoidal em torno da saia. Tal movimento se repete nas escadas do cenário de Marte e recorda o formato do Monumento à Terceira Internacional de Tatlin, de 1920 [Figura 14]. O monumento consiste no projeto para uma grande torre de aço em espiral, aprovada pelo Departamento Soviético de Belas Artes como símbolo do comunismo, porém rejeitada pelo próprio governo comunista por ser considerada utópica ${ }^{20}$. Além da afinidade formal, os trabalhos de Tatlin e de Exter compartilham outras características da vanguarda russa. Como aponta Bortullucce, os artistas construtivistas cultivavam a ideia da funcionalidade tecnológica e eficácia dos materiais industriais, com isso Tatlin utilizou metal, vidro e madeira em diversos trabalhos com o intuito de ressaltar as propriedades ${ }^{21}$ e a faktura (textura) de cada elemento num jogo de reflexão, transparência e solidez ${ }^{22}$, semelhante à estratégia de Exter na montagem dos personagens e do ambiente marciano para o filme em preto e branco.

A parte da vestimenta que cobre o busto de Aelita é composta por três formas arredondadas, a sugerir que esta mulher se distingue das terráqueas por possuir três seios. Além disso, Aelita tem um exótico acessório de cabeça, com diversas extensões pontiagudas. John Bowlt aponta que apesar de os trajes desenhados por Exter para os personagens de Aelita parecerem pesados e absurdos no papel, funcionaram perfeitamente no contexto do filme. ${ }^{23}$ De acordo com Sue-Ellen Case ${ }^{24}$, a imagem criada para a rainha de Marte é semelhante à da mulher burguesa anterior à revolução não apenas pelos costumes, mas pela riqueza com a qual o figurino foi elaborado. Esta observação é reforçada no enredo do filme pelo contraste entre o mundo utópico de Marte e a realidade de Moscou. As cenas que mostram a esposa do engenheiro Los, por exemplo, trabalhando no checkpoint dos imigrantes que chegavam em vagões de trens superlotados, com suas vidas abaladas pela guerra, contrastam com o reino de Aelita.

\footnotetext{
${ }_{20}$ PERLOFF, Marjorie. O momento futurista: avant-garde, avant-guerre e a linguagem da ruptura. São Paulo: Edusp, 1993, p. 389

${ }^{21}$ BORTULLUCCE, Vanessa Beatriz. A arte dos regimes totalitários do século XX. Editora Annablume, 2008, p. 83.

${ }^{22}$ PERLOFF, op. cit., p. 136.

${ }^{23}$ BOWLT apud CHRISTIE; TAYLOR, op. cit., p. 96. Tradução nossa.

${ }^{24}$ CASE, op. cit.
} 
Talvez estas questões tenham levado alguns críticos à interpretação da produção de Exter como formalista e decorativa:

\begin{abstract}
Os fatores estéticos dominam as criações de Exter para a Escola de Moda e seus projetos para os figurinos do filme Aelita. Em ambos os ramos de trabalho, as considerações de utilidade estrita não desempenharam nenhum papel, e o uso das formas geométricas de Exter como elementos decorativos enfatizou a natureza essencialmente pictórica de sua abordagem à roupa. O traje de Aelita se espalhava em protrusões de vegetais extravagantes mais reminiscentes do Art Nouveau do que do Construtivismo, e as calças de sua empregada, construídas de tiras metálicas

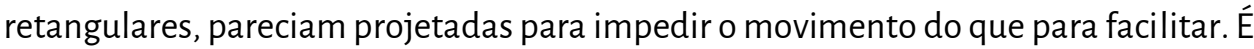
significativo que enquanto Stepanova e Popova usaram o teatro para realizar prozodezhda ${ }^{25}$ Exter produziu decorativos. ${ }^{26}$
\end{abstract}

Ao longo do filme, a personagem aparece com variações do figurino, como outro [Figura 15] em cores mais escuras, com recortes geométricos de tecido aplicados ao vestido e um capacete com detalhes em arcos e círculos. O design inovador também pode ser observado nos figurinos de outros personagens do filme, como da acompanhante de Aelita, que possui uma espécie de prótese mecânica móvel de acordo com o deslocamento corporal [Figuras 16 -17].

Se de um lado a crítica observou certo convencionalismo nos trajes do filme Aelita ao apontar reminiscências art nouveau, por outro os desenhos de Exter inovam com relação a ilustrações de seres marcianos em livros da época. Em Guerra dos Mundos, de H. G. Wells, o brasileiro Henrique Alvim Corrêa representou extraterrestres [Figuras 18 - 19] mesclando características robóticas - armas de ataque, cilindros, cones e círculos - e figurações monstruosas, por vezes animalescas - as pernas extremamente finas e compridas, semelhantes às de aracnídeos, e os olhos esbugalhados. Em outras representações, como as ilustrações dos livros de Edgar Rice Burroughs, os marcianos não possuem o aspecto robótico dos desenhos de Alvim Corrêa, mas na série Barsoom, alguns extraterrestres têm aspecto de monstros, comumente verdes com anomalias físicas, membros duplicados ou interpenetração de corpos [Figuras 20 -21]. Mais um exemplo de marciano com tais características é o do filme Viagem à Marte, de 1910 [Figura 22], com formato craniano incomum e orelhas compridas e pontiagudas.

Em Aelita, os marcianos são humanos e não têm aparência de monstros. O exotismo e as modificações no volume corporal dos extraterrestres do filme são sutis e aplicados por meio dos trajes, como os três seios da protagonista, as hastes flexíveis nas pernas de Masha, os adereços de cabeça e o aspecto rígido nos figurinos dos servos de Tuksub [Figura 23]. A inovação também ocorre na montagem

\footnotetext{
${ }^{25}$ Denomina-se Prozodezhda as roupas funcionais, elaboradas para cada tipo de trabalho. Muitos artistas da vanguarda Russa se empenharam na criação dessas roupas, entre eles Liubov Popova e Varvara Stepanova.

${ }^{26}$ CHRISTIE; TAYLOR, op. cit., p. 96. Tradução nossa.
} 
cenográfica projetada para Marte em um ambiente interno e tecnológico, diferente das representações a céu aberto, algumas com vegetação e animais. $\mathrm{O}$ ambiente marciano elaborado por Exter e Rabinovich para o filme difere até mesmo daquele descrito no romance de Alexei Tolstoi:

[...] os cactos agora eram mais altos, mais grossos e sólidos. Os homens tiveram que escolher o caminho cuidadosamente através do tremor. Animais muito parecidos com lagartos, alaranjados e brilhantes, com as costas escamosas. Bolas esquisitas de aspecto espinhoso afastaram-se e saltaram para dentro dos tentáculos da vegetação. Los e Gusev avançaram com muito cuidado ${ }^{27}$.

Nas ilustrações de capa do romance de Alexei Tolstoi existem outras representações de Aelita [Figuras $24-26] .{ }^{28}$ As propostas visuais para a rainha de Marte nas ilustrações são distintas daquelas desenhadas por Exter, pois nestas a personagem geralmente é representada com trajes mais tradicionais e uma esfera em suas mãos, aparentemente uma miniatura do planeta Terra sob o seu poder, ou em gesto de saudação, com os braços levantados para o alto e características semelhantes às descritas por Tolstoi no livro: "uma jovem mulher com um chapéu pontudo amarelo apareceu nos degraus. Ela parecia esbelta e jovem, azul e branca contra o maciço fundo de musgo"29. Pode se notar, no entanto, nas vestes da figura 24, a presença de fitas em espiral que mesmo convencionais não deixam de ecoar aspectos formais do desenho de Exter.

É possível que a ilustração da personagem na capa de uma das edições do livro de Tolstoi [Figura 26], quase em vestes de uma divindade antiga, evoque algo de primitivo da própria atmosfera do livro. Em alguns trechos, a descrição que Tolstoi faz do planeta Marte aponta indícios de características primitivistas, como os objetos comparados à arte Etrusca:

Los parou para examinar as esculturas na passagem. Entre o nariz pontiagudo das cabeças marcianas, as estátuas de monstros marinhos, máscaras pintadas e vasos, cujas formas e ornamentos eram curiosamente semelhantes aos dos Etruscos, [...] uma grande estátua de uma mulher nua com os cabelos desalinhados e uma face selvagem assimétrica. [...] Ela usava uma tiara de estrelas douradas, que formavam uma fina parábola em sua testa ${ }^{30}$.

\footnotetext{
27 TOLSTOI, Alexei. Aelita. Moscow: Foreign Languages Publishing House, p. 34 . Disponível em: https://archive.org/stream/AlexeiTolstoyAelita/Alexei-Tolstoy-Aelita\#page/n1/mode/2up. Acesso em: 06 jul. 2020 . Tradução nossa.

${ }^{28}$ Não foi possível descobrir as datas das edições dos livros aqui citados.

${ }^{29}$ TOLSTOI, op. cit., p. 60. Tradução nossa.

${ }^{30}$ Ibidem, p. 42. Tradução nossa.
} 
No filme Aelita, as formas pontudas que parecem irradiar energia da cabeça da Rainha de Marte, a abertura inovadora das portas do cenário, os capacetes dos marcianos com aspecto futurista, os trajes de Gor confeccionados com tubos de plástico, as máscaras, os robôs, as escadas em direções diversas, as colunas em arcos, o telescópio, os prismas, triângulos e transparências constituíram um mundo como nenhum outro capturado até então e ecoaram em produções posteriores do mesmo gênero ${ }^{31}$. Tais características também são proeminentes nas ilustrações dos cartazes do filme [Figura 27] e nas imagens que ilustram a capa do dvd, com a protagonista [Figura 28]

Com relação a outros experimentos artísticos, os moldes e materiais utilizados para a criação dos figurinos de Aelita recordam os trajes do Triadic Ballet [Figuras 29 - 30], de Oskar Schlemmer, elaborados na mesma década. A produção de Schlemmer apresentou a dança de vanguarda com inovadora coreografia e diversidade de figurinos que transformavam volumetricamente o contorno corporal e causavam efeitos extraordinários em movimento no espaço. As espirais em torno de um dos trajes do Triadic Ballet [Figura 30] rememoram a modelagem da saia da Aelita de Exter, bem como os capacetes, presentes na maioria dos personagens.

O adereço de cabeça projetado para Aelita é semelhante ao de personagens de outras produções do mesmo período. Em Aelita, as pontas brilhantes que envolvem a cabeça como uma auréola sugerem tanto algum tipo de irradiação luminosa - por ser uma produção de ficção científica atrelada à proposta futurista - quanto o esplendor da posição ocupada por Aelita na sociedade em que vive. As personagens do ballet The Midnight Sun [Figura 31] e da comédia The Brass Bottle [Figura 32], ambos produzidos na década de 1920, também possuem acessórios com aspecto semelhante, tal como o desenho de Fedorovsky [Figura 35] para o Lago dos Cisnes, no teatro Bolshoi, a ilustração de Mucha para Medea [Figura 33], e até mesmo o adereço na cabeça da Liberdade de Bartholdi [Figura 34].

No âmbito da ficção científica, não podemos deixar de mencionar outra importante produção da mesma década. Dirigido por Fritz Lang em 1927, Metropolis foi baseado no romance de Thea Von Harbou e teve grande repercussão entre as obras do mesmo gênero. O filme se passa em 2026, na metrópole onde vivem o magnata Fredersen e seu filho Freder, em contraste à cidade subterrânea dos operários e oprimidos. Freder, ao conhecer a cidade subterrânea, encontra Maria, por quem se apaixona. Fredersen, porém, para impedir o relacionamento entre os dois, pede a Rotwang que crie um robô com a imagem de Maria, com o intuito de subverter o caráter da jovem. Tal atitude causa conflito entre os trabalhadores e resulta no acidente que coloca em perigo a vida da população, levando Fredersen a selar um acordo com os operários.

\footnotetext{
${ }^{31} \operatorname{Ver}$ CHRISTIE; TAYLOR, op. cit.
} 
Em Metropolis, o robô criado pelo cientista Rotwang [Figura 36] foi construído inteiramente em metal, com movimentos mecânicos. Nesse aspecto, embora o robô também seja caracterizado como figura feminina, está em contraste à marciana Aelita, que apesar de pertencer a outro planeta é nitidamente uma mulher. Apesar de não compartilhar semelhanças visuais com Aelita, o robô possui, por outro lado, aspectos da arte de vanguarda do período, pois remete aos desenhos feitos por outra artista russa contemporânea a Exter, Liubov Popova. Em estudos e pinturas de corpos femininos sob uma proposta Construtivista [Figura 37], Popova representou mulheres estruturadas por blocos geométricas, em nuances metálicas, que não deixam de recordar a figuração do personagem de Metropolis.

Em Metropolis, embora o robô inicialmente apresente características visuais andróginas, sua identidade feminina é revelada quando, para causar conflitos entre os operários, Rotwang concede a ele a aparência de Maria, uma mulher admirada pela classe trabalhadora. Em determinado momento, a "robô-Maria" evoca a imagem da prostituta do apocalipse [Figura 38], e executa uma dança erótica a seduzir os homens a sua volta. Nesta cena, o acessório de cabeça usado pela personagem também apresenta extensões brilhantes e formato semelhante ao contorno de auréola.

Como podemos observar, os adereços de cabeça com aspecto futurista são elementos presentes em diversas produções teatrais e cinematográficas do mesmo período de Aelita. Nos figurinos desenhados por Exter, eles foram aplicados a todos os habitantes de Marte. Porém, o acessório projetado para Aelita destoa dos demais personagens do filme por possuir extensões pontiagudas a contornar a cabeça. Para os outros figurinos, ainda que construídos com materiais e formatos inusitados, os acessórios e capacetes não resultam em conformação semelhante. Em meio aos preceitos vanguardistas do filme, observamos ecos de representações do passado. Notamos que as soluções visuais projetadas por Exter parecem fazer referência a elementos simbólicos do âmbito religioso, a atribuir à rainha de Marte uma imagem de caráter sagrado. Um dos elementos é a auréola, presente em representações artísticas míticas e religiosas [Figuras 39 - 40] para enfatizar a sacralização dos seres.

Outro indício, embora menos forte, está nas três formas circulares que compõem o busto das vestes da personagem, que, para além de sugerir a distinção de Aelita em relação às mulheres terráqueas, pode remeter à deusa Meenakshi (ou Parvati) da cultura hindu, por possuir três seios. No desenho de Exter, talvez em fuga à literalidade, os círculos sobre os seios de Aelita foram dispostos oblíqua e assimetricamente, com tamanhos ligeiramente distintos, acompanhando também os elementos em diagonal ou espiral do vestido [Figura 41]. Podemos supor que há uma espécie de busca por equilíbrio entre elementos arcaizantes e modernizantes na elaboração dos figurinos do filme. 
Os trajes do filme podem ser comparados aos figurinos de outra produção teatral do mesmo período, cuja narrativa é inspirada na mitologia grega. De acordo com Bowlt, Aelita tem algo em comum com a "simplicidade e severidade"32 dos figurinos de A. Vesnin para a peça Phedra, de 1922 [Figura 42]. Além disso, a descrição de Guinsburg sobre os trajes da peça, bem como sua interferência na movimentação e gestualidade dos personagens, parece ser aplicável também aos figurinos de Aelita, principalmente aqueles com caracterização robótica e mecanismos estruturais na composição das vestes:

As amplas roupagens a panejar as figuras, os vastos capacetes e toucados em metal dourado a lavrar as cabeças e os calçados de solas altas ao modo de coturnos endureciam a movimentação, impunham a cunhagem gestual elaborada e essencializada, convertendo os corpos dos atores em esculturas vivas, maciças e hieráticas. ${ }^{33}$

Os trajes masculinos do filme também apresentam semelhanças com a indumentária do passado, como o personagem Tuksub [Figura 43], governante de Marte, cujo figurino é composto pela saia na altura dos joelhos, o colete, do qual se estende a longa capa escura, e o rígido capacete construído em placas geométricas, a ecoar o vestuário que se costuma atribuir aos guerreiros egípcios ou romanos, como podemos observar em comparação mais uma vez aos Horácios de David [Figura 44]. A presença de elementos visuais ancestrais em Aelita é corroborada por Sue-Ellen Case ao apontar que os trajes da Rainha de Marte e de sua criada evocam características orientais, vindo a sugerir a possibilidade de tais figurinos serem criações reminiscentes dos projetos para Salomé:

Os trajes espetaculares para a Rainha Aelita e sua criada imitam a alta moda dos ricos. Eles combinam calças orientalistas do harém (talvez um conceito de figurino deixado da produção de Salomé de Wilde) com formas geométricas. Tanto a rainha quanto sua empregada usam halter tops ${ }^{34}$, revelando partes desnudas dentro dos dispositivos geométricos. ${ }^{35}$

A aproximação dos figurinos de Aelita às características orientais fica evidente ao comparar detalhes do projeto de Exter às pinturas de odaliscas, profusamente retratadas no século XIX e no início do XX. Os círculos que cobrem os seios da Rainha de Marte [Figura 46] são semelhantes aos das vestes da odalisca de Douglas ]oseph [Figura 45] e da Salomé interpretada por Maud Allan [Figura 47]. Ambas

\footnotetext{
${ }^{32}$ BOWLT, John E. Constructivism and Russian Stage Design. Performing Art Journal, v. 1, n. 3, 1977, p. 62-84, p. 71. Tradução nossa.

${ }^{33}$ CUINSBURG, ]. Stalinavski, Meierhold e Cia. São Paulo: Perspectiva, 2001, p. 187.

${ }^{34}$ Halter tops referem-se às blusas curtas, que cobrem os seios e deixam o ventre despido, semelhante ao que denominamos bustiê, no Brasil.

${ }^{35}$ CASE, op. cit., p. 113. Tradução nossa.
} 
apresentam bordados e aplicações em pedrarias aos contornos circulares com aspecto brilhante, como no traje principal de Aelita. A atmosfera orientalista ressoa ainda mais na cena em que Aelita toca uma espécie de harpa adaptada ao cenário marciano, enquanto Tuksub se aproxima [Figura 48]. Esta imagem também evoca o ambiente representado em diversas pinturas do século XIX, sobretudo a Odalisca com escravo, de Ingres [Figura 49]. Ambas, além de exibirem a figura do músico recorrente a esta abordagem temática, apresentam semelhanças na montagem da cena: Aelita tem posição similar à da instrumentista de Ingres, e a posição de Tuksub se parece com a da escrava.

Alguns segundos depois, Aelita continua a tocar a harpa enquanto Tuksub descansa, deitado no sofá [Figura 50]. Esta imagem rememora representações de odaliscas em situação de relaxamento, com seus corpos a derreter entre os tecidos fluidos sobre os quais repousam, ao som da melodia tocada pela instrumentista que as acompanha [Figuras 51 - 52]. Além disso, a comparação entre estas imagens apontam a subversão quanto ao gênero representado, enquanto no século XIX tais personagens eram predominantemente femininas, em Aelita trata-se de um homem em momento de ócio, sonolento, enquanto as duas mulheres atuam ativamente a sua volta.

A pose de Tuksub adormecido [Figura 53] também recorda a de A Bacante [Figura 54] de Courbet, e a Mulher com narguile, de Cormon [Figura 56]. Ambos compartilham semelhanças no corpo reclinado e na posição de cabeça e braços, a remeter, enfim, à Messalina de Henrique Bernardelli [Figura 55], a qual, nas palavras da pesquisadora Camila Dazzi, "faz uma evidente referência à Messalina histórica, eleita, no oitocentos, o arquétipo da mulher bela, viciada em sexo, totalmente sem caráter, sem escrúpulos e perigosa" ${ }^{36}$, características estas igualmente atribuídas à Salomé, a reforçar o orientalismo disfarçado da cena e o elo que aproxima soluções cênicas e visuais em Aelita às de produções anteriores de Exter, notadamente de Salomé.

Mesmo que o tema desse à artista maior liberdade de lidar com figurações novas e preceitos vanguardistas, não devia ser fácil desvencilhar-se das referências que a cercavam. A reflexão em torno das imagens de Aelita convalida o uso paradoxal de representações visuais historicistas, às vezes predecessoras, às vezes contemporâneas, para a construção de um ambiente de ficção científica. O liame entre o exótico e o primitivo influiu tanto às produções cenográficas exuberantes de mundos passados quanto do espaço sideral, ou seja, a artista retoma o passado enquanto referência e inspiração, a constituir a atmosfera futurista com sobrevivências visuais "primitivistas".

\footnotetext{
${ }^{36}$ DAZZI, Camila. Relações Brasil-Italia na arte do Segundo oitocentos: estudos sobre Henrique Bernardelli (1880 a 1890). Dissertação (Mestrado em História) - Instituto de Filosofia e Ciências Humanas, Unicamp, 2006, p. 135. Disponível em: http://www.repositorio.unicamp.br/bitstream/REPOSIP/281528/1/Dazzi_CamilaCarneiro_M.pdf. Acesso em: 06 jul. 2020.
} 


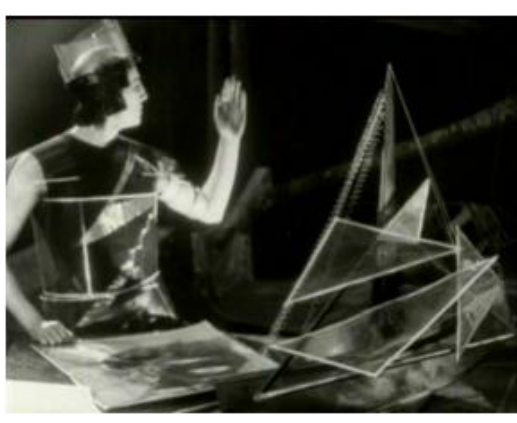

Figura 1:

Fotograma do filme Aelita, Rainha de Marte, 1924.

Fonte: LEZO, 2010, p. 104.

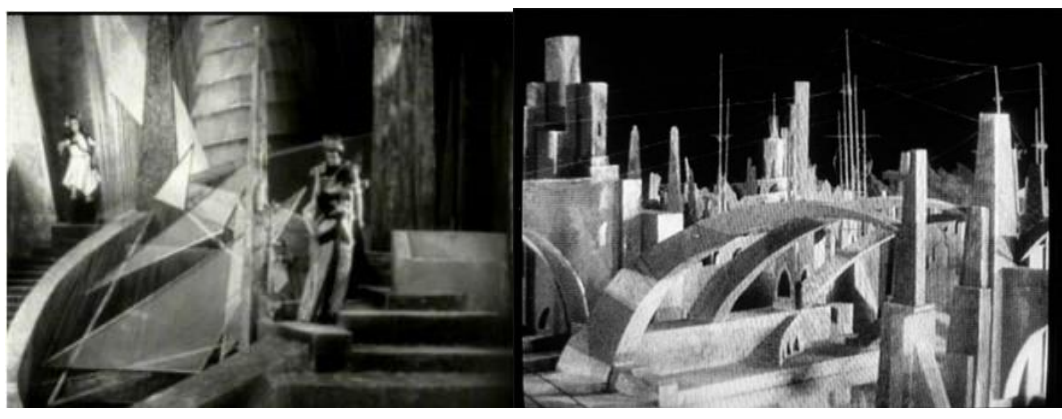

Figura 2:

Fotograma do filme Aelita, Rainha de Marte, 1924.

Fonte: LEZO, 2010, p. 104

\section{Figura 3:}

Fotograma do filme Aelita, Rainha de Marte, 1924.

Fonte: LEZO, 2010, p. 99.

Figura 4: Albert Robida, Caricatura para Le Vingtième Siècle, c.1890. Fonte: https://goo.gl/CqXwVQ. Acesso em: 20 dez. 2016.

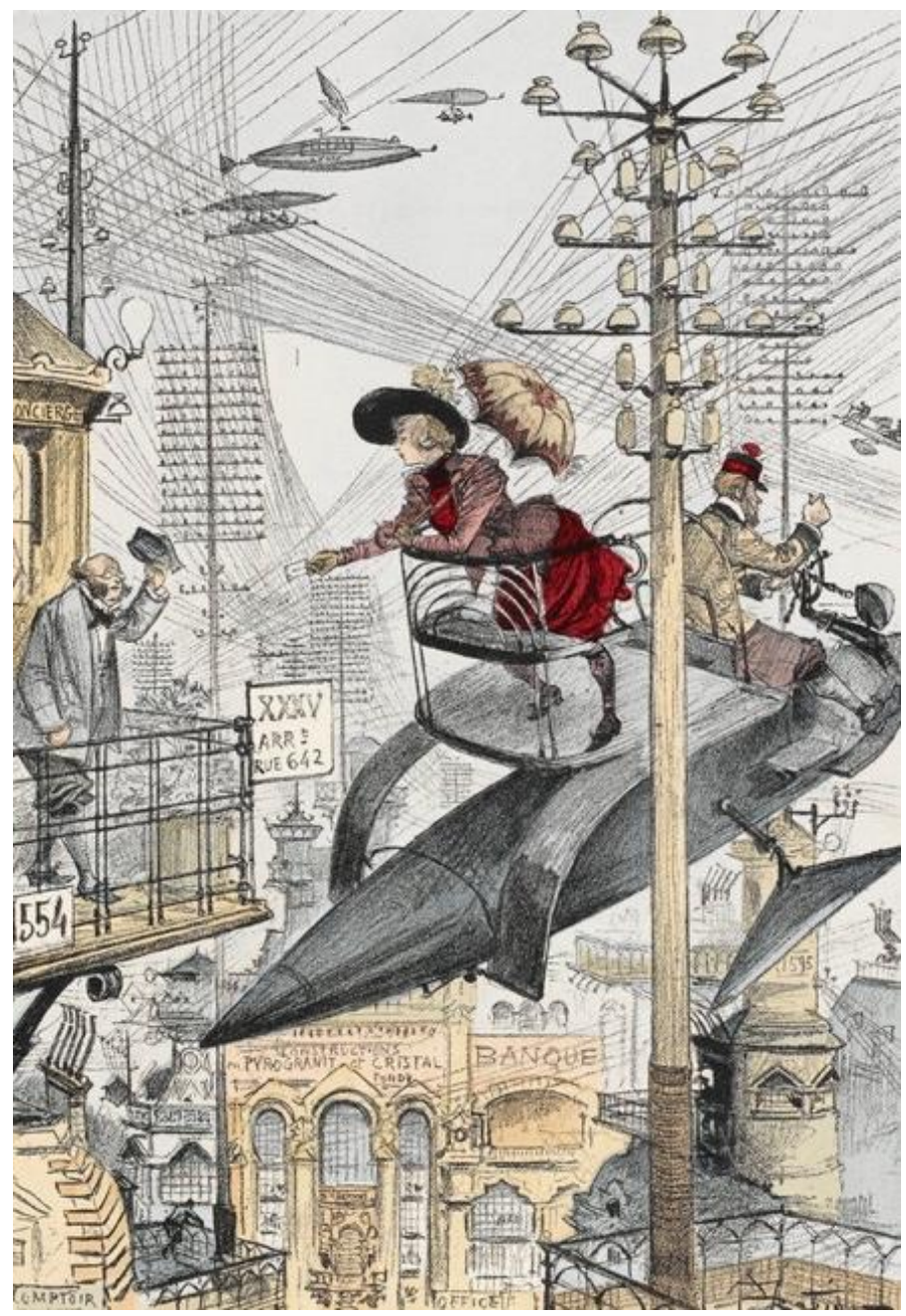




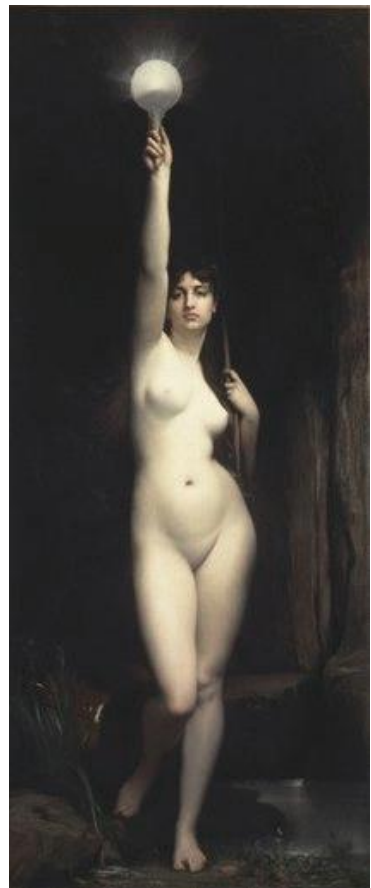

Figura 5:

Jules Lefebvre, La Vérité, 1870. Óleo sobre tela.

Fonte:

https://goo.gl/zNXp2WAc esso em: 02 mar. 2017.

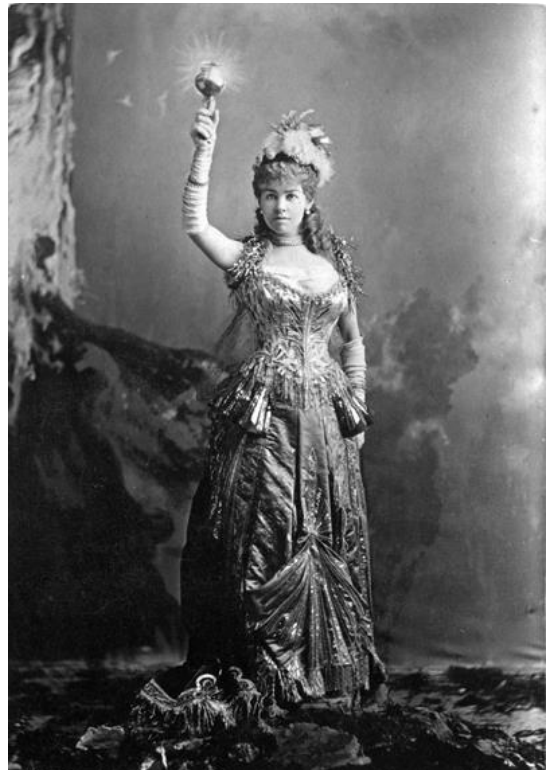

Figura 6:

Sra. Cornelius Vanderbilt vestindo Electric Light dress, 1883.

Fonte: https://goo.gl/Pi8WcL. Acesso em O2 mar. 2017.

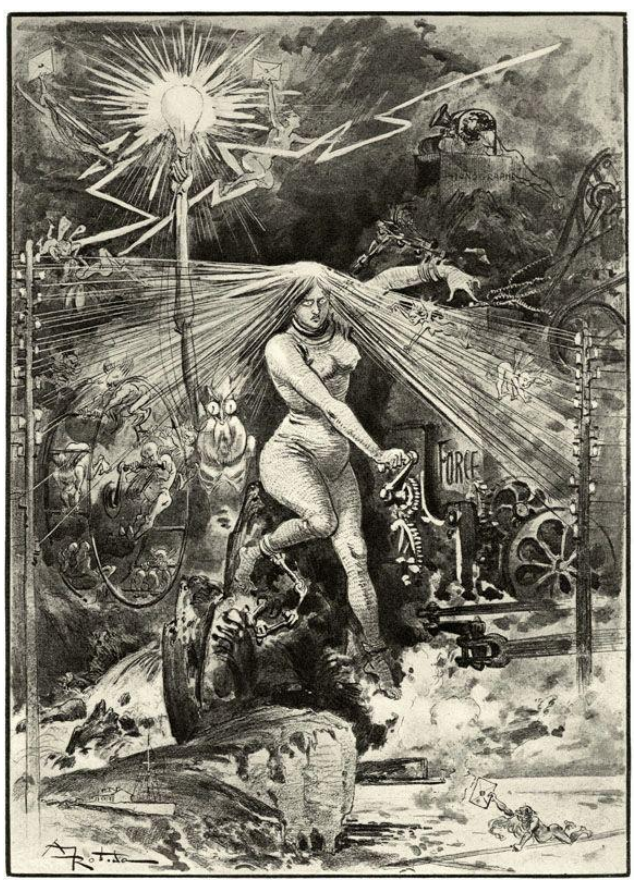

Figura 8:

Albert Robida, Musa intitulada L'Électricité (la grande esclave), em La Vie électrique, 1890, Paris.

Fonte: WOSK, 2003, p. 71

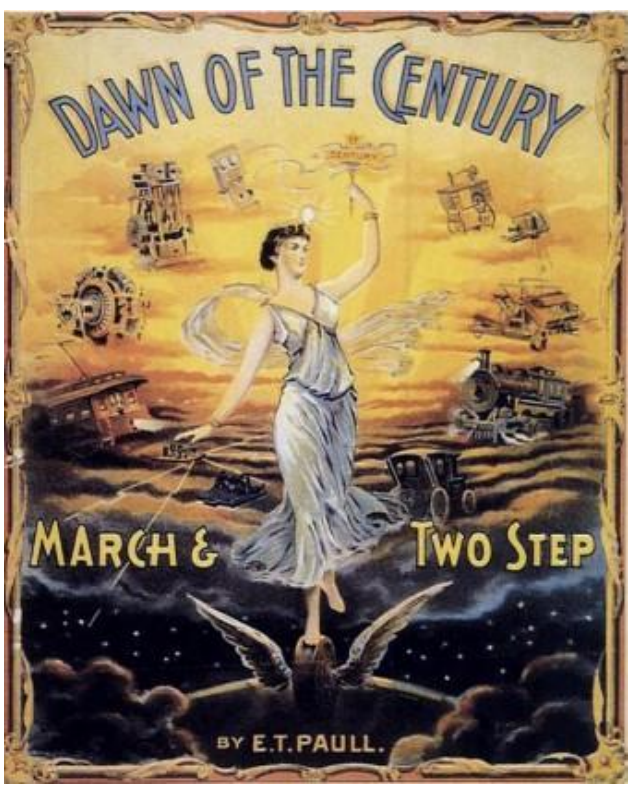

Figura 7:

Dawn of the Century, march and twostep, 1900. Partitura de E. T. Paull.

Fonte: WOSK, 2003, p. 75

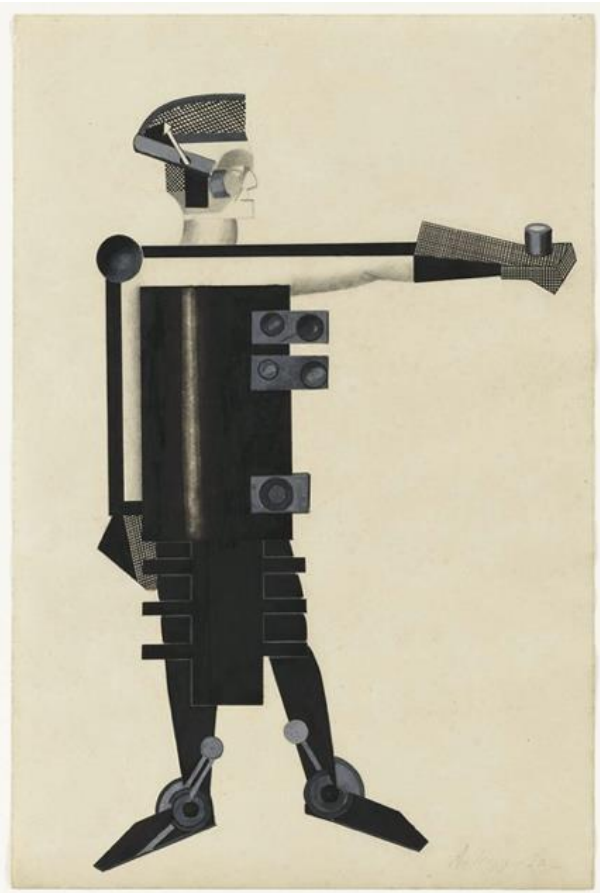

Figura 9:

Alexandra Exter, Guardião da

Energia, 1924. Guache e lápis sobre papel, $54 \times 36,2 \mathrm{~cm}$.

Fonte: https://goo.gl/DbyDDE. Acesso em: 02 mar. 2017. 

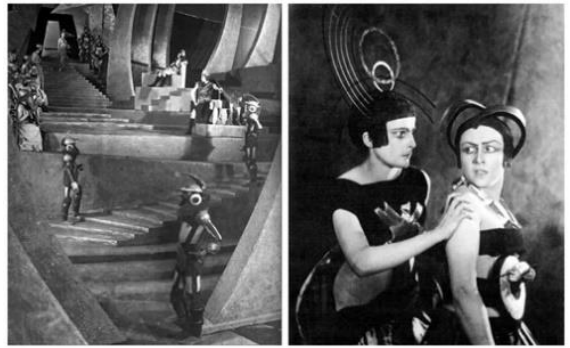

\section{Figura 10:}

Cena do filme Aelita, Rainha de

Marte, 1924, com diversos guardiões da energia

Fonte: https://goo.gl/k6yGhE. Acesso em: 03 mar. 2017

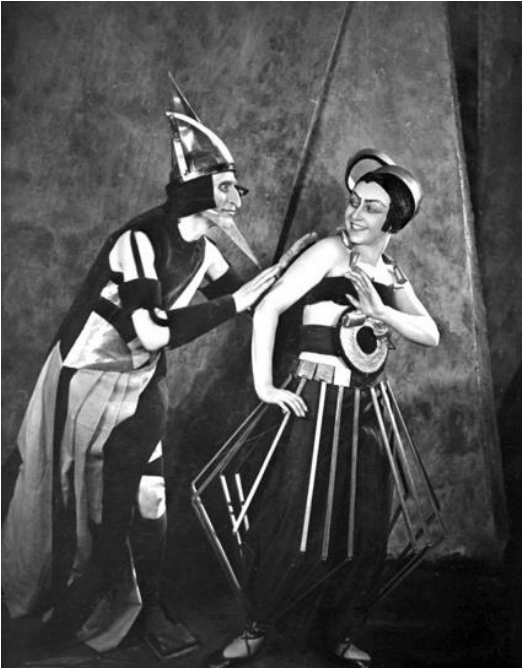

\section{Figura 11:}

Cena do filme Aelita, Rainha de Marte, 1924, figurinos desenhados por Alexandra Exter. Fonte: STRIZHENOVA, 1991, p. 123.

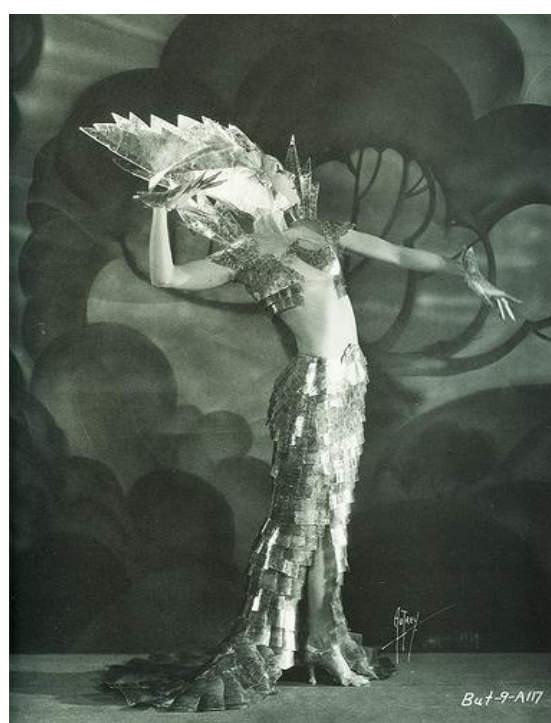

\section{Figura 12:}

Rainha de Marte do filme Just Imagine, 1930, figurino desenhado por Sophia Wachner.

Fonte: https://goo.gl/ADEoCF. Acesso em: 06 mar. 2017.

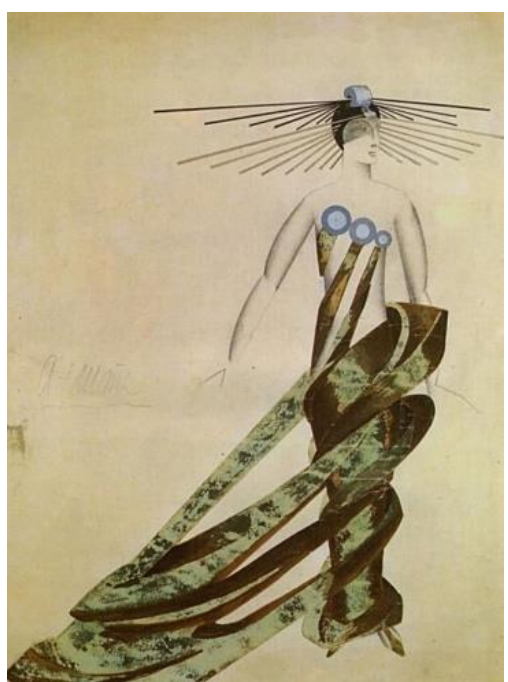

Figura 13:

Alexandra Exter, desenho de figurino para Aelita em Aelita, Rainha de Marte, 1924.

Fonte: STRIZHENOVA, 1991, p. 122

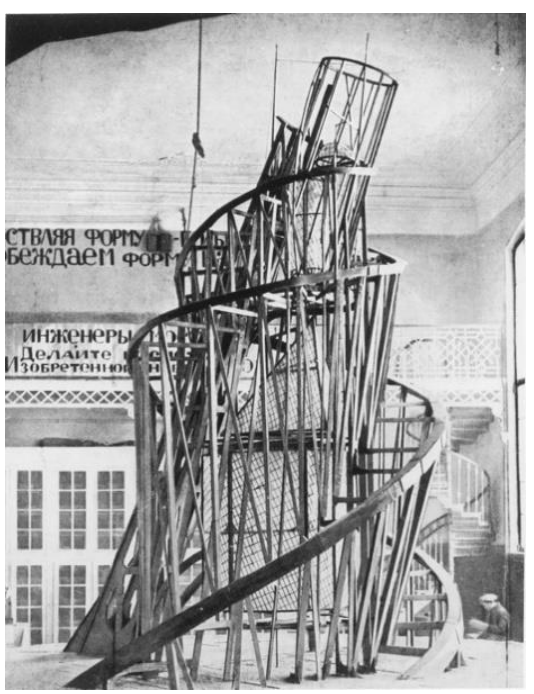

\section{Figura 14:}

Modelo do Monumento à Terceira Internacional, 1920, construído por Tevel Shapiro, Sofia Dymshits, losif Meerzon, e Pavel Vinogradov sob direção de Tatlin.

Fonte: https://goo.gl/2RVa7C. Acesso em: 02 mar. 2017.

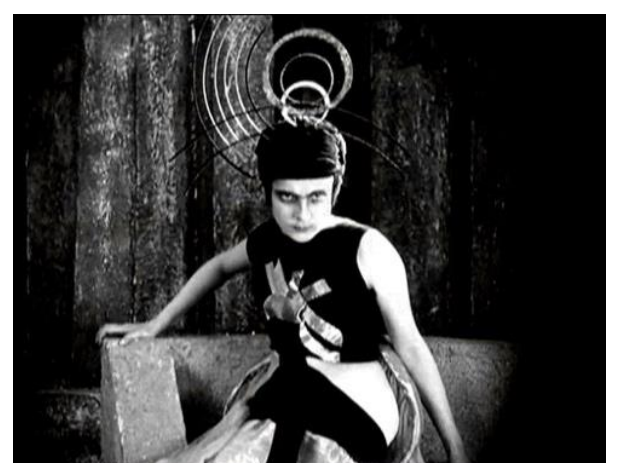

Figura 15:

Screenshot do filme Aelita, Rainha de Marte, 1924.

Disponível em: https://goo.gl/OlK9Tk. Acesso em: 06 mar. 2017. 


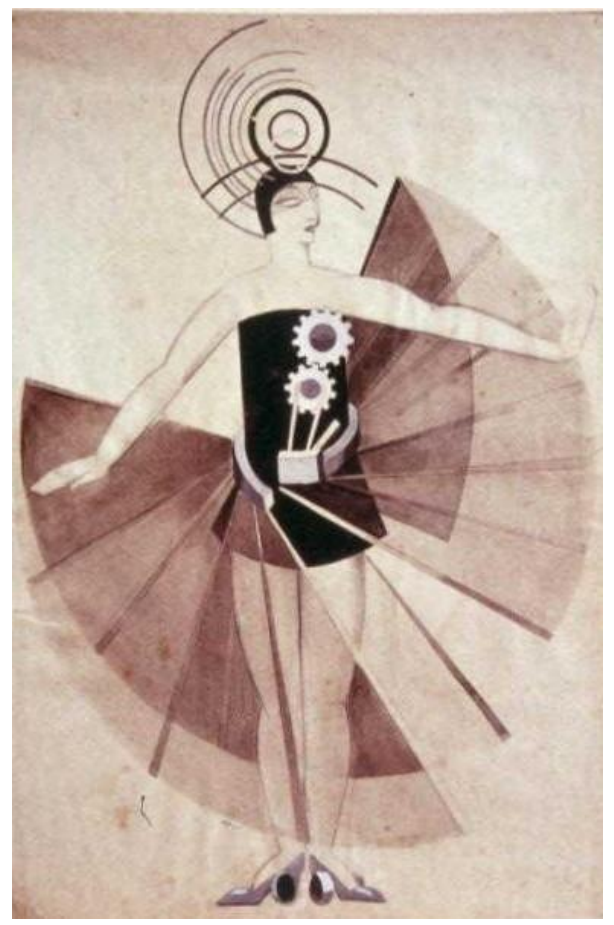

Figura 16:

Alexandra Exter, desenho de figurino para Aelita, Rainha de Marte, 1924.

Fonte: https://goo.gl/yGTope. Acesso em: 20 dez. 2016.

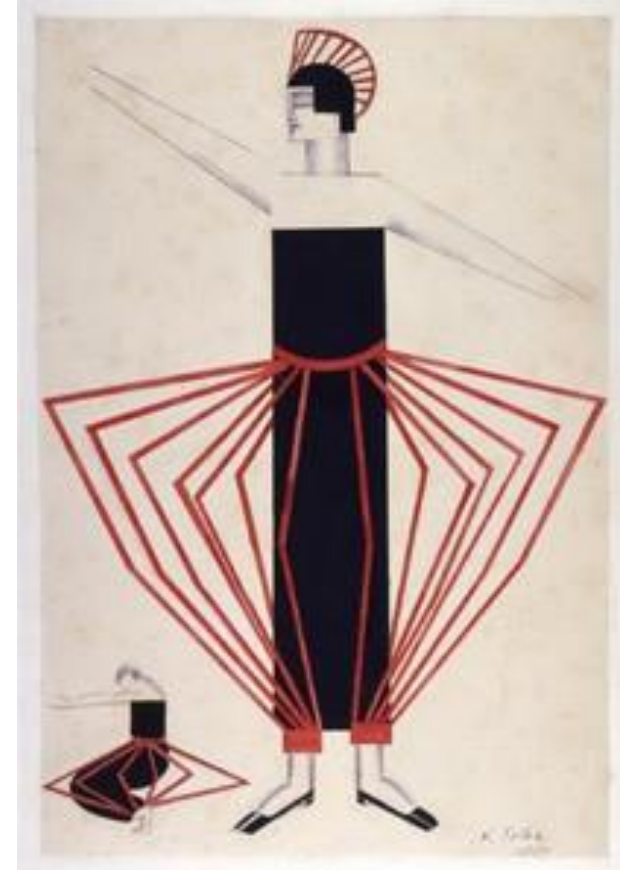

Figura 17:

Alexandra Exter, desenho de figurino para Aelita, Rainha de Marte, 1924.

Fonte: https://goo.gl/yGTope. Acesso em: 20 dez. 2016
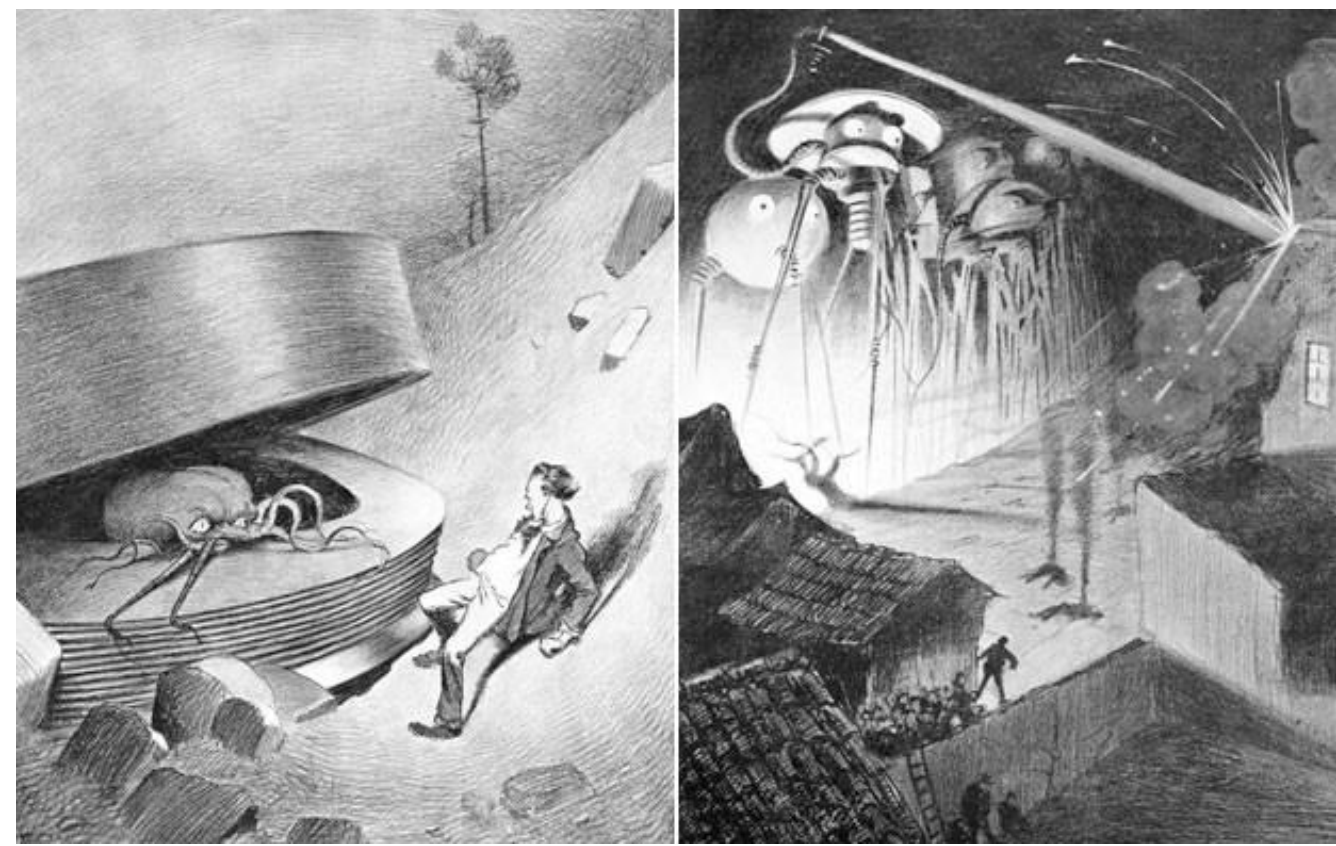

Figuras 18-19:

Henrique Alvim Corrêa, Guerra dos Mundos, de H. G. Wells, 1906. Ilustração.

Fonte: https://goo.gl/p6K1F5. Acesso em: 02 mar. 2017. 


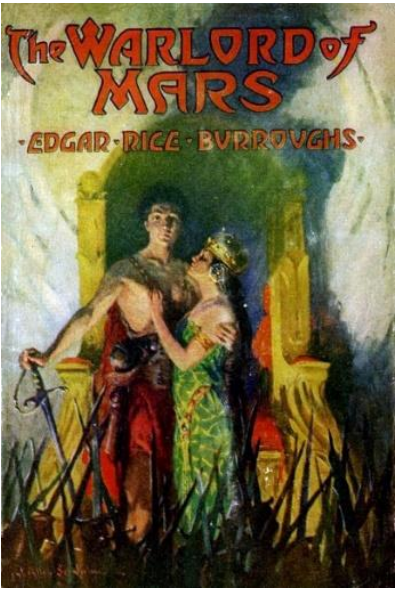

Figura 20:

Capa do livro de Edgar Rice Burroughs, 1919.

Fonte: https://goo.gl/KvKMmG. Acesso em: 10 mar. 2017.

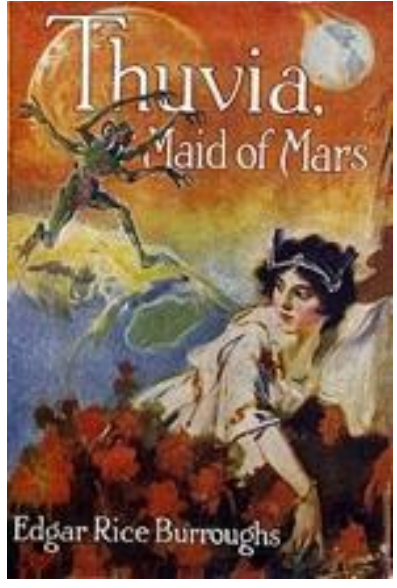

\section{Figura 21:}

Capa do livro de Edgar Rice Burroughs, 1920.

Fonte: https://goo.gl/KvKMmC. Acesso em: 10 mar. 2017.

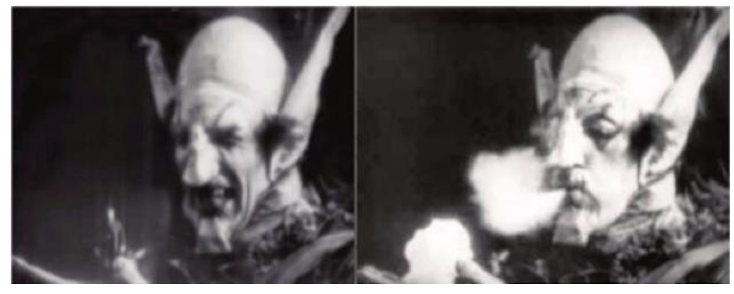

\section{Figura 22:}

Marciano do filme Viagem à Marte, dirigido por Ashley Miller, Thomas A. Edison Company, 1910.

Fonte: MILLER, Thomas Kent. Mars in the Movies: a history. McFarland, 2016, p. 18.

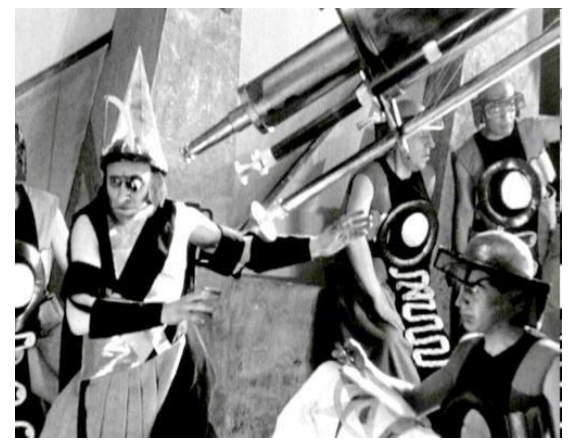

Figura 23:

Screenshot do filme Aelita, Rainha de Marte, 1924.

Disponível em: https://goo.gl/5RtCBO. Acesso em: 06 mar. 2017.

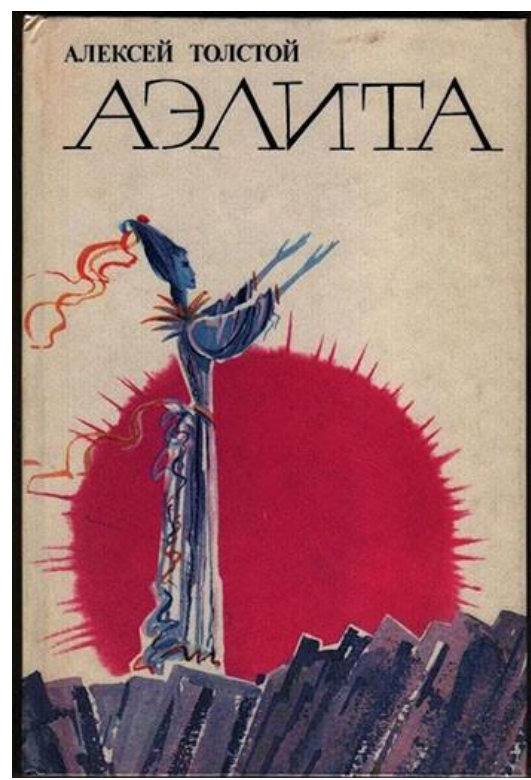

\section{Figura 24:}

Capa do livro Aelita, de Alexei Tolstoi.

Fonte: https://goo.gl/sn1Rp1. Acesso em: 20 dez. 2016.

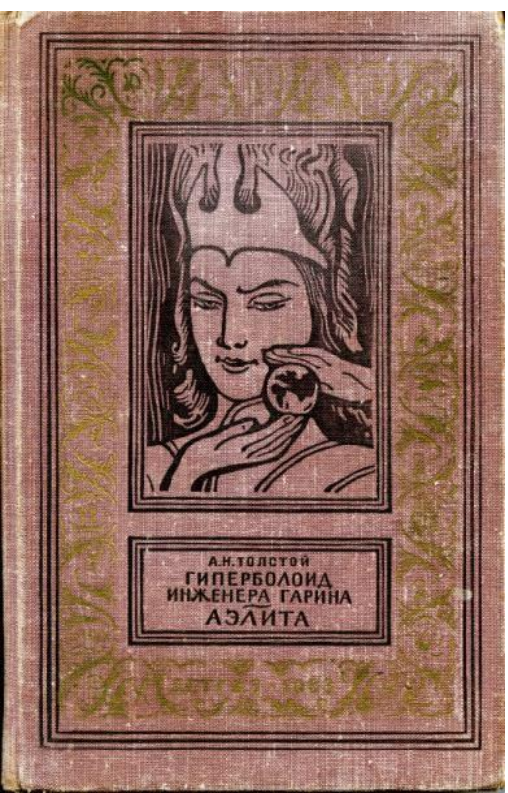

Figura 25:

Capa do livro Aelita, de Alexei Tolstoi.

Fonte: https://goo.gl/sn1Rp1. Acesso em: 20 dez. 2016. 


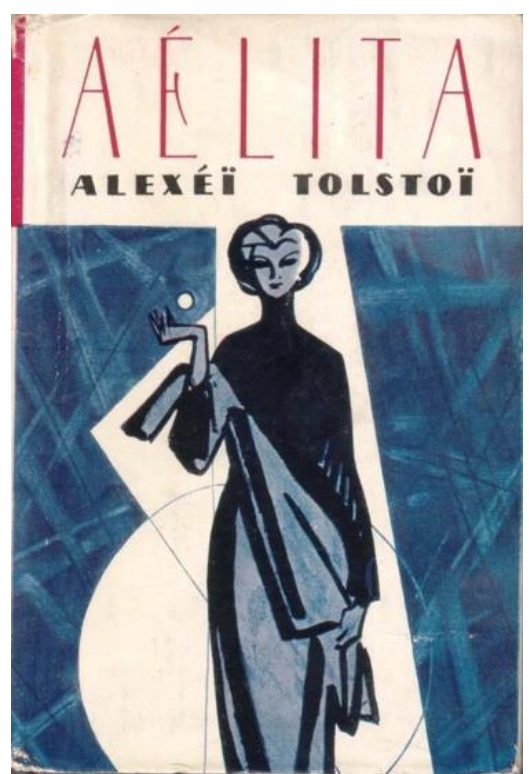

Figura 26:

Ilustração de capa do livro Aelita, de Alexei Tolstoi.

Fonte: TOLSTOI, capa, Acesso em: 10 mar. 2017.

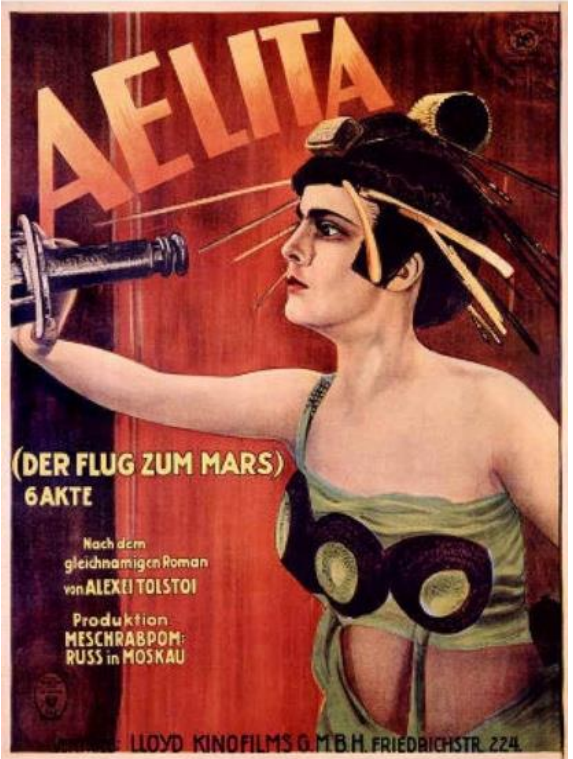

Figura 27:

Cartaz do filme Aelita, Rainha de Marte.

Fonte: https://goo.gl/F1/Wjh. Acesso em: 27 fev. 2017.

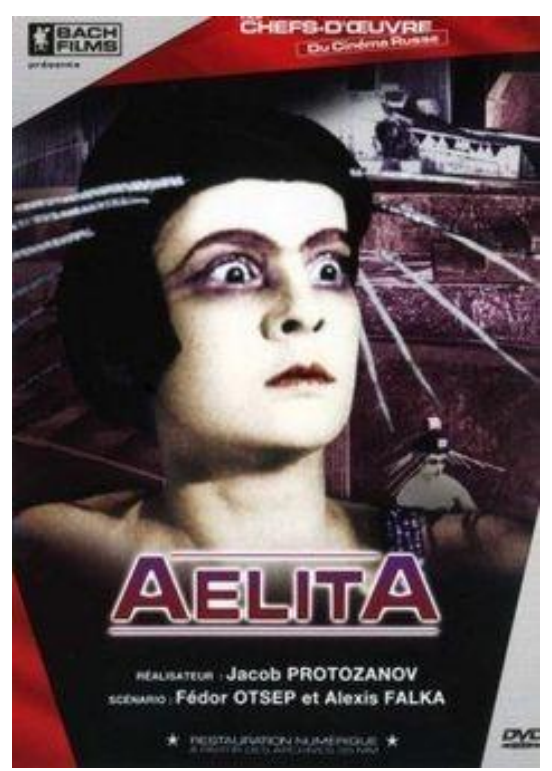

Figura 28:

Capa do dvd do filme Aelita, Rainha de Marte.

Fonte: https://goo.gl/nNWtof. Acesso em O3 mar. 2017.

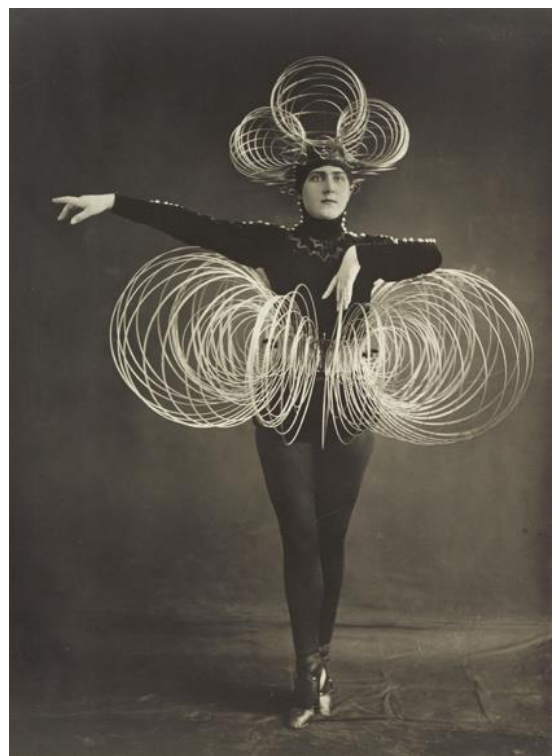

Figura 29:

Oskar Schlemmer, figurino para Tradic Ballet, 1926, 22,5 x 16,2 cm.

Fonte: https://goo.gl/TM9asC. Acesso em: 02 mar.2017.

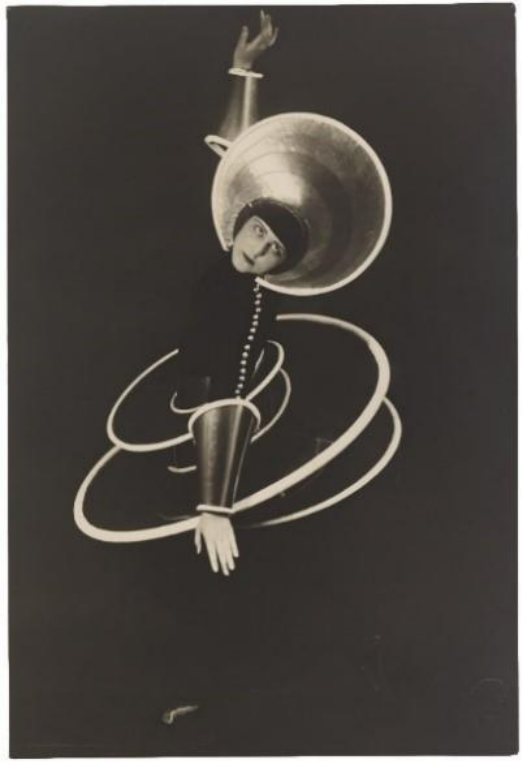

\section{Figura 30:}

Oskar Schlemmer, figurino para Tradic Ballet, 1926.

Fonte: https://goo.gl/ZIFgZn, Acesso em: 02 mar.2017.

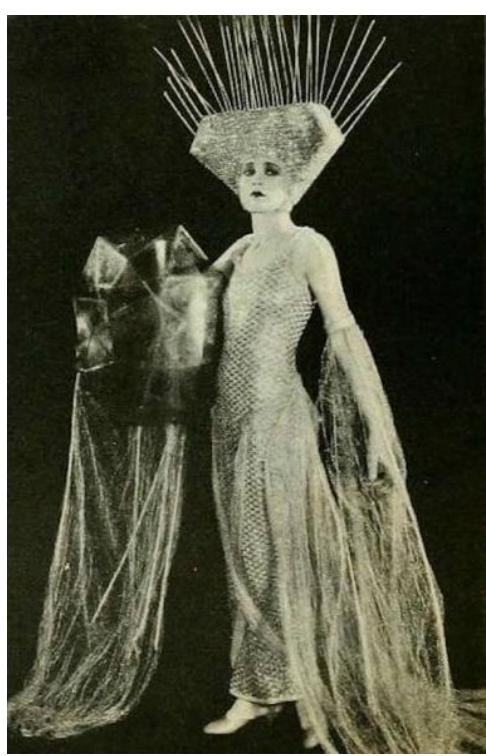

Figura 31:

Figurino para ballet The Midnight Sun, 1920. 
Figura 32:

Barbara La Marr em The

Brass Bottle, 1923.

Fonte: https://goo.gl/VCbm6R. Acesso em: 20 dez. 2016.

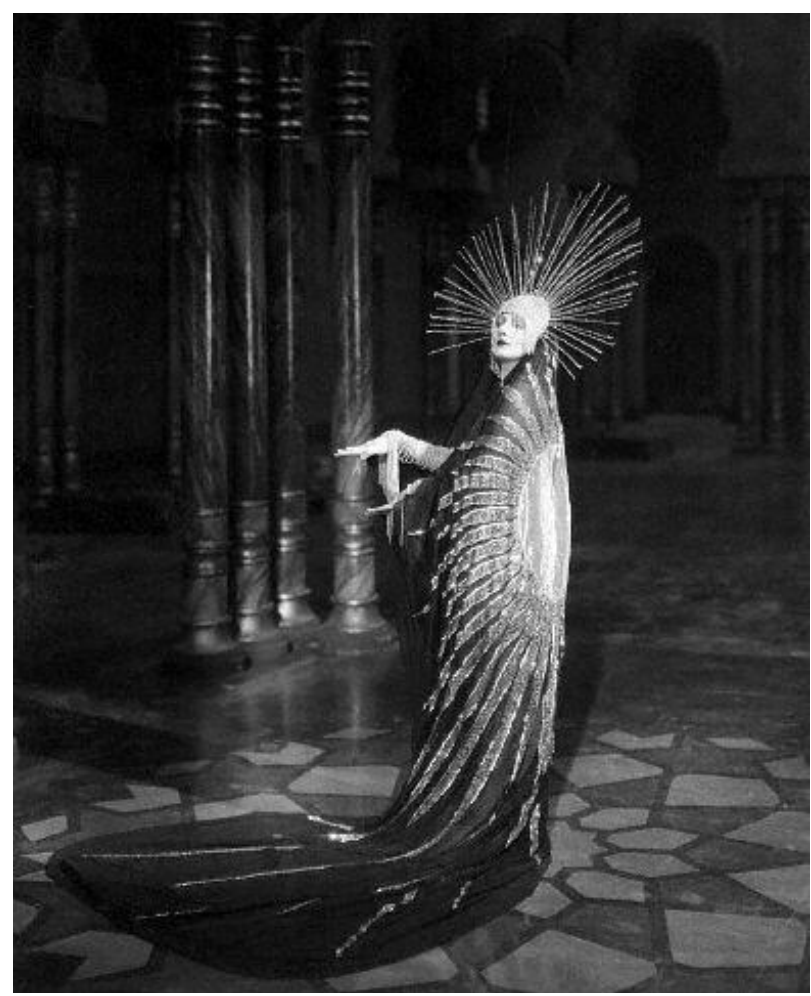

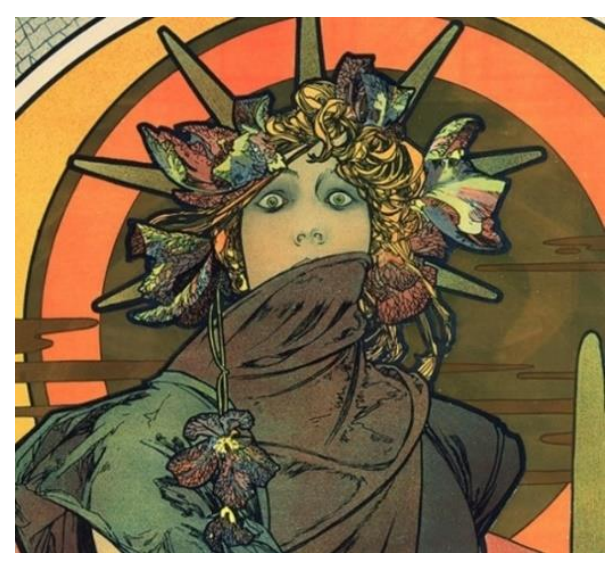

Figura 33:

Alphonse Mucha, detalhe do pôster para Medea, 1894.

Fonte: https://goo.gl/e6z7AB. Acesso em: $21 \mathrm{dez}$. 2016.

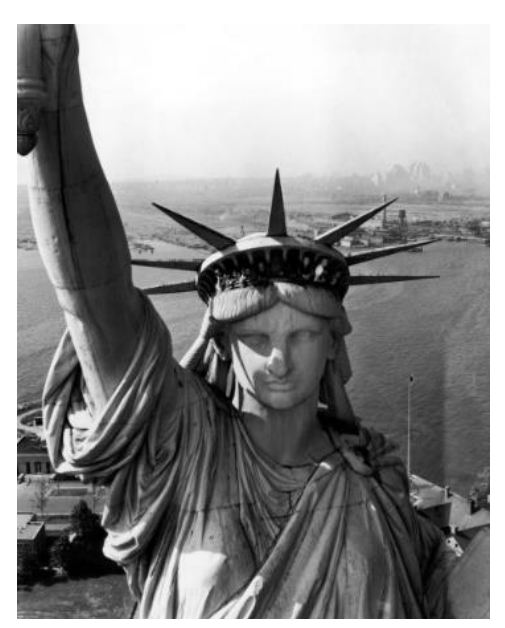

Figura 34:

Bartholdi, Liberdade, c. 1870, fotografia de 1951.

Fonte: Website Time - Margaret Bourke-White-Time \&amp; Life Pictures-Getty Images

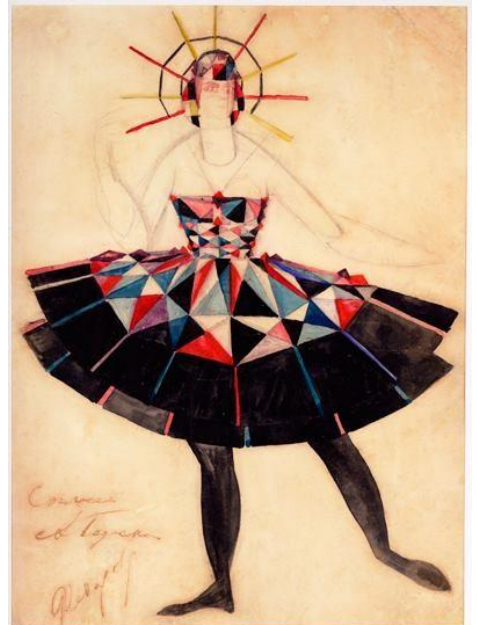

\section{Figura 35:}

F. Fedorovsky, desenho para figurino de Lago dos Cisnes, 1921, de Tchaikovsky, Teatro Bolshoi, Moscou.

Fonte: https://goo.gl//mCWxY. Acesso em: 21 dez. 2016. 


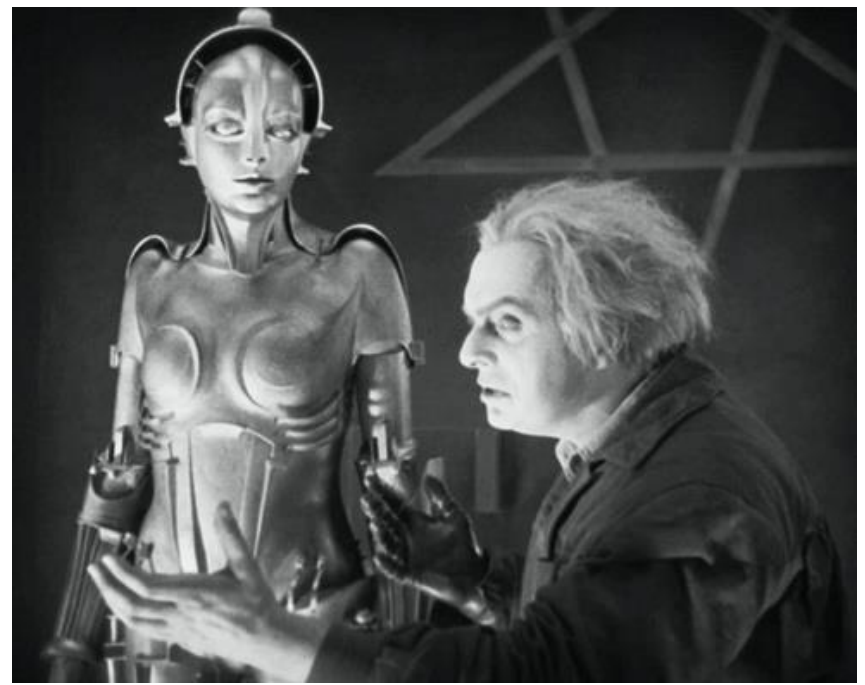

Figura 36:

Cena do filme Metropolis, de Fritz Lang, 1927.

Fonte: https://goo.gl/SfpBMI. Acesso em: 12 dez. 2016.

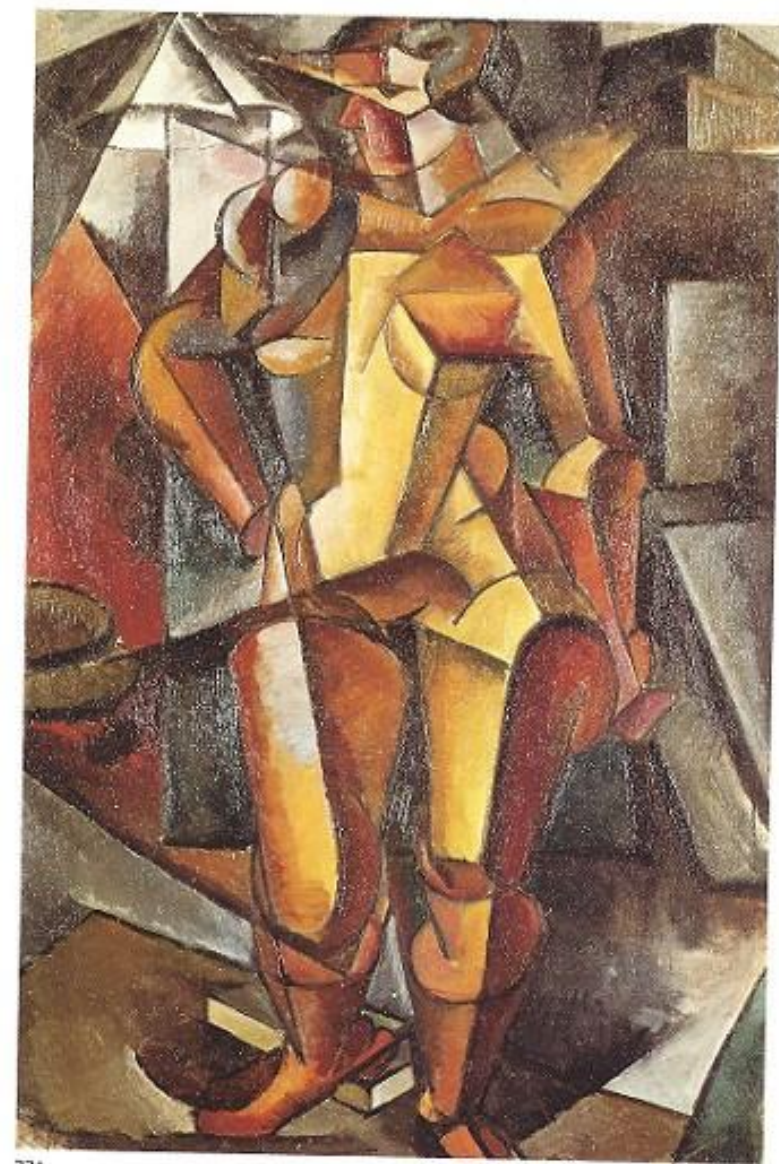

Figura 37:

Liubov Popova, Modelo feminino, 1913-14.

Óleo sobre tela, $105 \times 69,5 \mathrm{~cm}$

Fonte: RUDENSTINE, Angelica Zander (Edição). Russian Avant-Garde Art: The George Costakis Collection. Thames and Hudson, 1981.

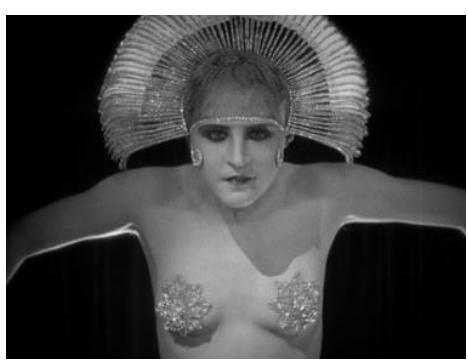

Figura 38:

Cena do filme Metrópolis, de Fritz Lang, 1927.

Fonte: https://goo.gl/zRnPEs. Acesso em: 12 dez. 2016.

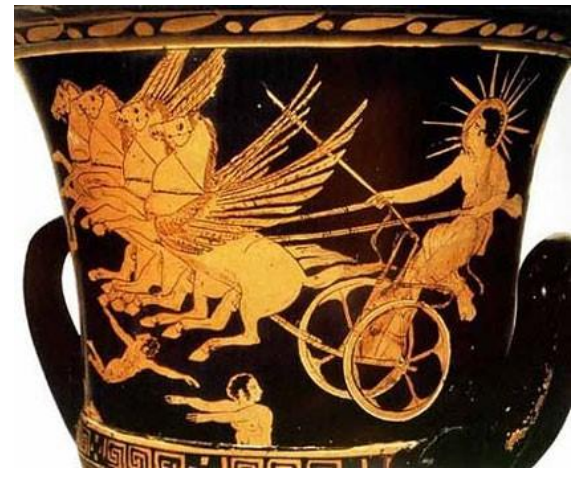

Figura 39:

Detalhe de vaso grego com Helios, deus do sol.

Fonte: Wikimedia Commons Images.

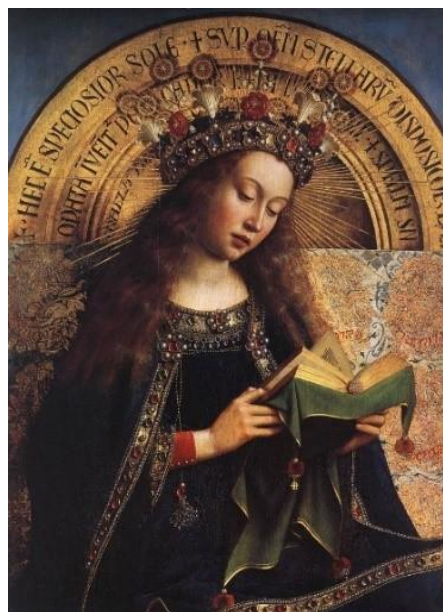

Figura 40:

Jan Van Eyck, Retábulo de

Ghent, 1432 (detalhe).

Fonte: Wikimedia Commons Images. 


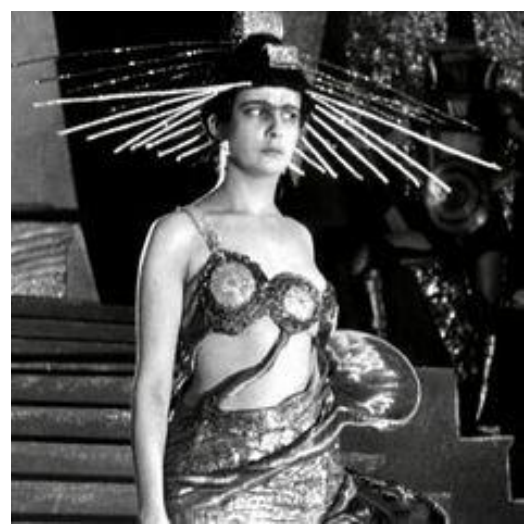

Figura 41:

Screenshot do filme Aelita, Rainha de Marte, 1924.

Disponível em: https://goo.gl/SXWTCq. Acesso em: 06 mar. 2017.

\section{Figura 44:}

Jacques-Louis David, Os três irmãos Horácios, 1785. Giz preto, lavagem e destaques em branco, $580 \times 450 \mathrm{~cm}$, Musée Monnat, França.

Fonte: https://goo.gl/bAh2NI. Acesso em: 20 dez. 2016

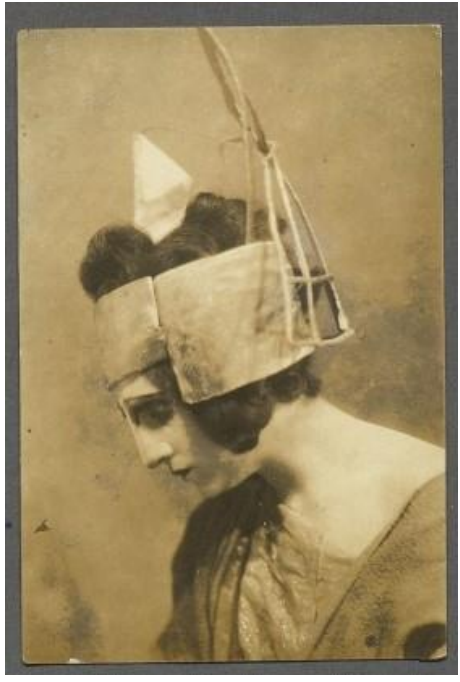

\section{Figura 42:}

Fotografia de Alisa Koonen como Phaedra, 1922, Russian State Archive of Literature and Art.

Fonte: https://goo.gl/GpLsYm. Acesso em: 12 dez. 2016.
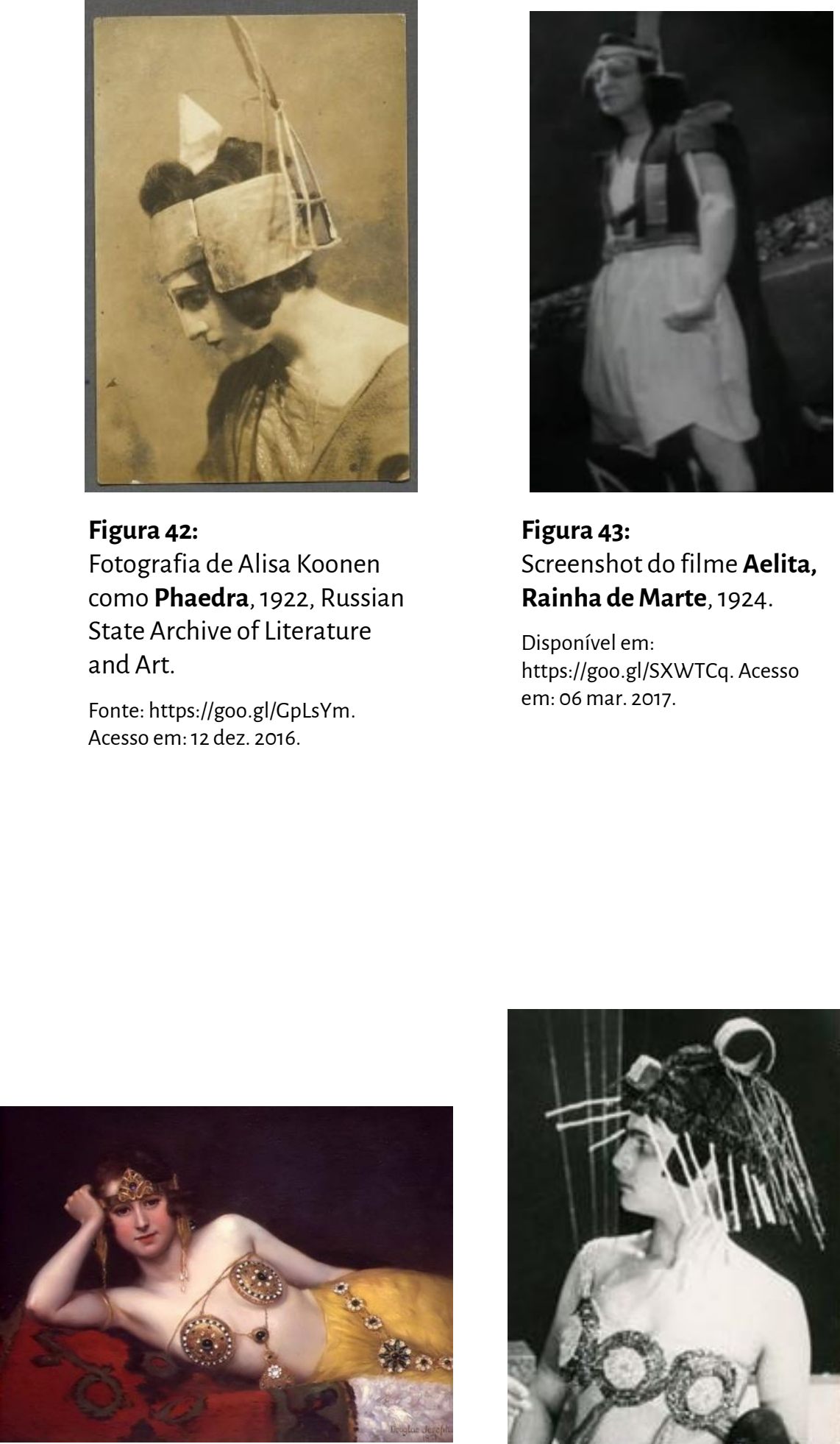

Figura 43:

Screenshot do filme Aelita, Rainha de Marte, 1924.

Disponível em:

https://goo.gl/SXWTCq. Acesso em: 06 mar. 2017.

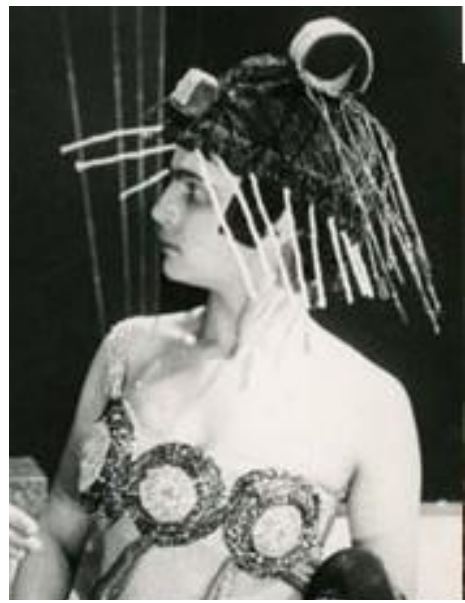

Figura 45:

Douglas Joseph, Odalisca, 1921. Óleo sobre tela.

Fonte: https://goo.gl/AhdA65. Acesso em: 02 dez. 2016.
Figura 46:

Screenshot do filme Aelita, Rainha de Marte, 1924.

Disponível em: https://goo.gl/PjY7gi. Acesso em: 06 mar. 2017. 


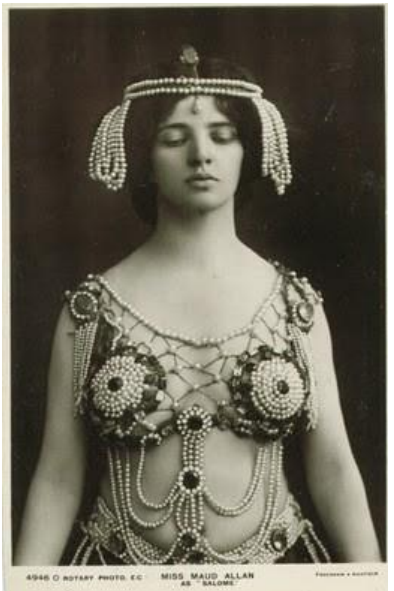

Figura 47:

Fotografia de Maud Allan como Salomé, 1908.

Fonte: https://goo.gl/qT2cSp. Acesso em: 02 dez. 2016

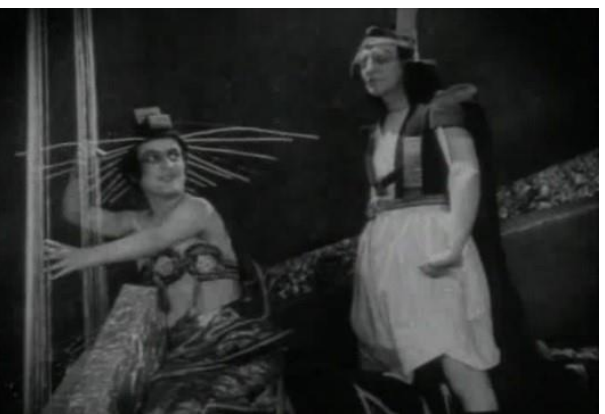

Figura 48:

Screenshot do filme Aelita, Rainha de Marte, 1924.

Disponível em: https://goo.gl/NTNafQ. Acesso em: 06 mar. 2017.

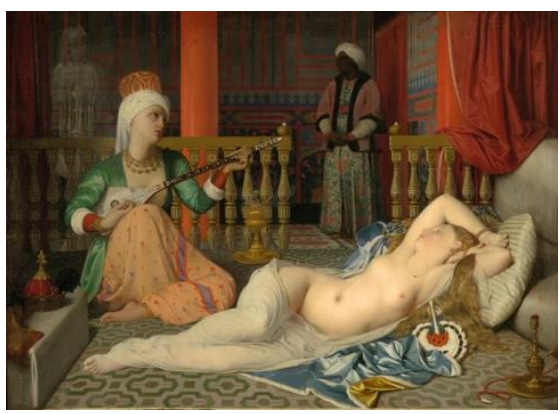

Figura 49:

Jean Auguste Dominique Ingres, Odalisca com escravo, 1839-40. Óleo sobre tela, $72.1 \times 100.3 \mathrm{~cm}$, Harvard Art Museums Collection. Fonte: https://goo.gl/oKlz]l. Acesso em 02 dez. 2016

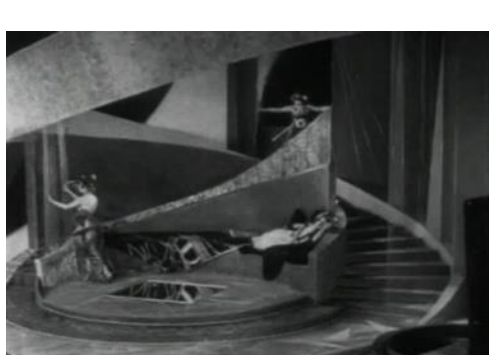

Figura 50:

Screenshot do filme Aelita, Rainha de Marte, 1924.

Disponível em: https://goo.gl/NTNafQ. Acesso em: 06 mar. 2017.

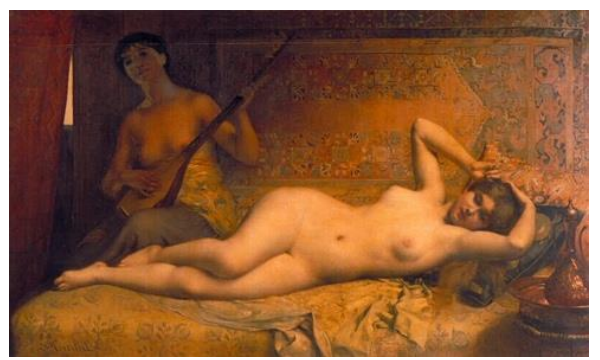

Figura 51:

Louis Courtat, A Odalisca, s.d.

Fonte: https://goo.gl/LQcxMD. Acesso em 02 dez. 2016.

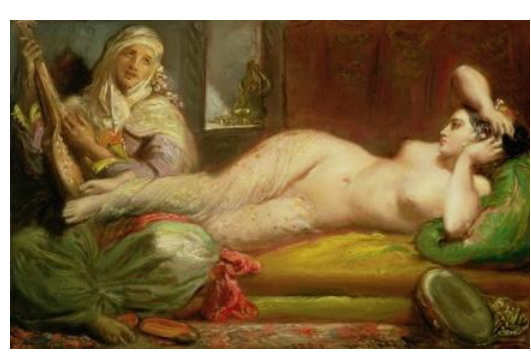

Figura 52:

Theodore Chasseriau, Odalisca reclinada, 1853 . Óleo sobre tela. Fonte: https://goo.gl/mKxq2p. Acesso em 02 dez. 2016. 


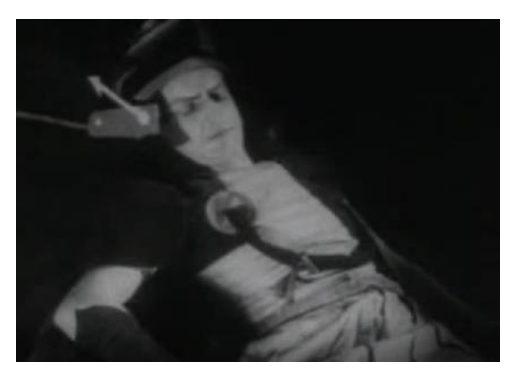

Figura 53:

Screenshot do filme Aelita, Rainha de Marte, 1924.

Disponível em: https://goo.gl/sT3vUd. Acesso em: 06 mar. 2017

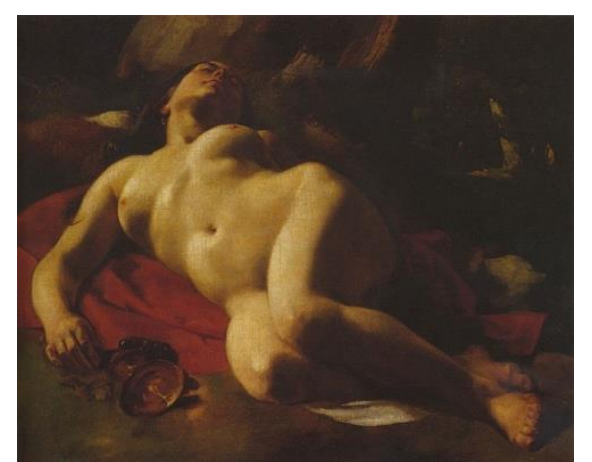

Figura 54:

Gustave Courbet, A Bacante, 18441847. Óleo sobre tela, $65 \times 81 \mathrm{~cm}$.

Fonte: https://goo.gl/ut]Cgy. Acesso em 02 dez. 2016.

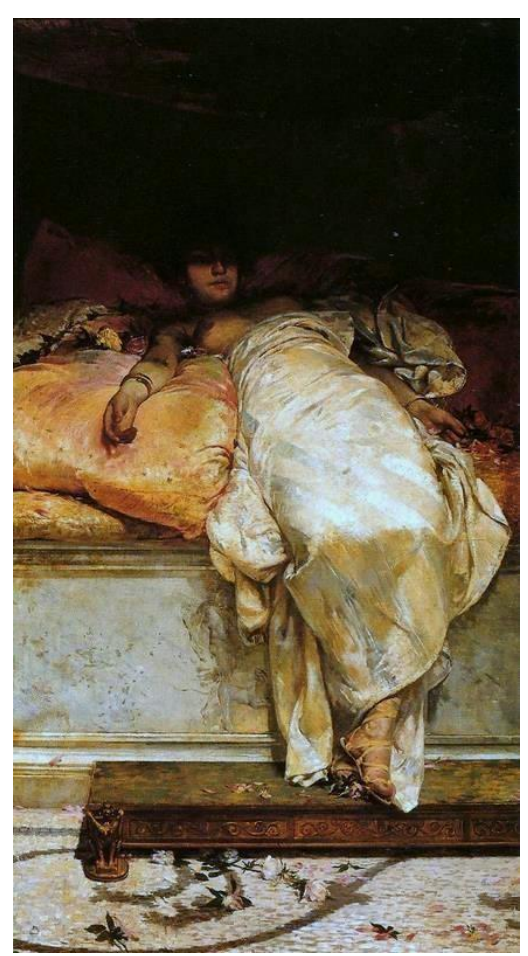

\section{Figura 55:}

Henrique Bernardelli, Messalina, 1878. Óleo sobre tela, $207 \times 115 \mathrm{~cm}$

Fonte: https://goo.gl/NDogra. Acesso em 02 dez. 2016.

Figura 56:

Fernand Cormon, Mulher com narguile, 1878. Óleo sobre painel, $35 \times 26 \mathrm{~cm}$, coleção particular.

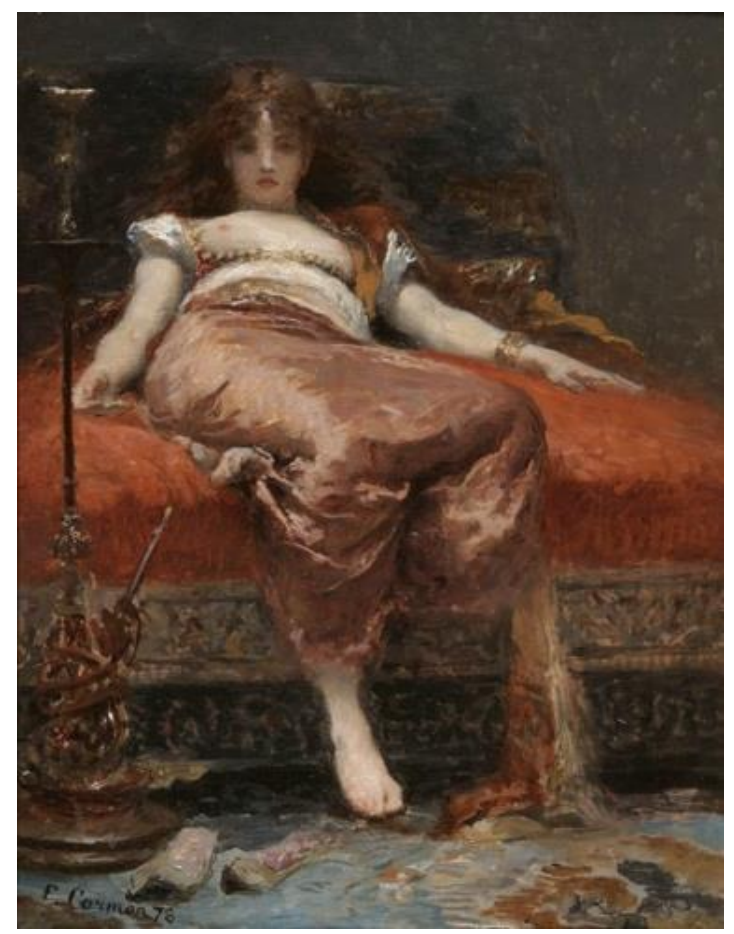

